\title{
Colombia-United States Free Trade Agreement. An observation to the Colombian agricultural microeconomy projected towards development
}

Melissa Stephanni Vargas Franky ( $\square$ melissa.vargas00@gmail.com )

USC: Universidad Santiago de Cali https://orcid.org/0000-0001-6000-5485 José Rodrigo Núñez

USC: Universidad Santiago de Cali

\section{Research}

Keywords: Colombia, Free Trade Agreement, competitiveness, food sovereignty, agricultural microeconomics.

Posted Date: December 23rd, 2020

DOI: https://doi.org/10.21203/rs.3.rs-132807/v1

License: (c) (i) This work is licensed under a Creative Commons Attribution 4.0 International License.

Read Full License 


\section{Title Page}

\section{Words counter: 7273}

Title: Colombia-United States Free Trade Agreement. An observation to the Colombian agricultural microeconomy projected towards development

\section{Names of the authors and affiliations}

Melissa Stephanni Vargas Franky: Master in Law with emphasis in Public Law-Research

Modality Santiago de Cali University. Investigative Lawyer graduated from Santiago de

Cali University (Valle del Cauca, Colombia). Email: melissa.vargas00@ gmail.com.

José Rodrigo Núñez Montes: Lawyer. Doctor of Law 1977 San Buenaventura University (USB). Specialized in University Research and Pedagogy (USB) 2004. Specialized in International Cooperation- USB 2004. Master in Public Management-Santiago de Cali University (USC) 2014. College Professor from 1988 to the date. Research group: GICPODERI -USC-2020. Valle del Cauca, Colombia. Email: jose.nunez00@usc.edu.co. 


\section{Abstract}

Through this article, the results of the Free Trade Agreement between Colombia and the United States were addressed, based on its effects on the exports of the Colombian agricultural sector and its repercussions on the rural microeconomy, using the following methods: a) Descriptive b) Comparative Method c) Revealed Comparative Advantages (RCA) and d) Prospective Approach, being the main variables, competition, rural poverty in Colombia, concentration of rural property and the investment budget destined for the vulnerable agricultural sector, observing that Colombia's agricultural products do not have significant comparative advantages to compete with the North American market, which is evidenced in the deficit trade balance. Colombia is the most unequal country in the distribution of land in Latin America where the largest extensions are destined to the production of agrofuels and it is the small farmers who generate the largest number of crops for internal consumption, persisting despite the hostile conditions in the Colombian countryside, and the high rates of monetary and multidimensional poverty. These circumstances pose a risk to the country's food sovereignty by becoming dependent on imports, which is why a legal-economic proposal was made for Colombia based on the United Nations Declaration of the Right to Development.

\section{Keywords}

Colombia, Free Trade Agreement, competitiveness, food sovereignty, agricultural microeconomics. 


\section{Introduction}

The economic opening of Colombia to the world market has meant an important step towards development, economic exchange and ensuring success in the international arena, however, after 8 years since the entry into force of the Trade Promotion Agreement between Colombia and the United States, the results are not very encouraging due to Colombia has few opportunities to take advantage of the benefits of freely trading agricultural products with the United States, so it is essential to improve its competitiveness (Stellian \& Danna, 2017), a scenario that is evident in the limited exportable supply of Colombian products, the highest percentage of which is limited to "primary" products.

Colombia's trade balance with the United States has been in deficit since 2014, reporting a deficit of $-1,079.7$ (millions of dollars FOB) in 2019 according to the National Administrative Department of Statistics-DANE (2020a), being one of the causes, subsidies to domestic production that generate market distortions as stipulated by the World Trade Organization (2016) where the case of the American Farm Bill is located.

In contrast, the level of monetary poverty in rural Colombia is considerably high, standing for the year 2019 at $47.5 \%$ compared to $32.3 \%$ in the urban sector, and a Multidimensional Poverty Index of $34.5 \%$ in rural areas, compared to $12.3 \%$ in urban capitals (DANE, 2020 b, c). In the same vein, the World Report on Internal Displacement (2019) places Colombia in second place of the ten countries with the highest number of people displaced by conflict and violence at the end of 2018, with 5.1 million people.

On the other hand, The Oxford Committee for Famine Relief (Oxfam, 2017) in its Report Radiography of Inequality, reports that Colombia is the country with the greatest 
inequality in distribution of land in Latin America according to the Gini coefficient, since $1 \%$ of the largest farms manage more than $80 \%$ of the land, while the remaining $99 \%$ is distributed less than $20 \%$. The largest amount of land in Colombia is dedicated to the agroindustrial group according to the National Agricultural Survey (National Agricultural Survey ENA-DANE, 2020 d).

This confirms the importance of small agriculture in the country, since small agricultural producers contribute a little more than half of the production at the national level, with about $80 \%$ of coffee production and with a third of the value of livestock production (The Colombian peasant, between economic protagonism and society's ignorance, Forero, 2010), and when analyzing "The economic efficiency of large, medium and small Colombian agricultural producers", it is concluded that agricultural producers, regardless of the scale of their productive activity, they manage to be efficient when they access social favorable environmental conditions (Forero, J., Garay, LJ, Barbieri, F., Ramírez, C., Suárez, DM, \& Gómez, R. 2012).

However, the investment budget assigned to the vulnerable agricultural sector in the Current Multi-year Investment Plan - PPI (Law 1955 National Development Plan 20182022) is worrying, compared to the budget allocated in the law of the Second National Development Plan (2014 -2018) of President Juan Manuel Santos (Law 1753 of 2015).

Thus, the purpose of this research was to analyze the results of the Free Trade Agreement between Colombia and the United States, focused on the agricultural sector and making an observation of the Colombian rural microeconomy as a catalyst for agricultural development, due to there is a threat to the sovereignty and food security of the country, 
given the impossibility of producing enough food to satisfy internal demand and become a nation dependent on foreign imports.

\section{Methodology}

\subsection{Descriptive method.}

The methodology of this research is initially developed from the Descriptive Method (Abreu, 2015) aimed at observing the results of the Free Trade Agreement between Colombia and the United States in the agricultural sector, taking into account the concepts of asymmetries, equity and reciprocity used by the Constitutional Court in its Approving Sentence C-751 of 2008.

\subsection{Revealed Comparative Advantages Method (RCA).}

To calculate the comparative advantages of Colombian products versus those of the United States, the method of the Center for Prospective Studies and International Information-CEPII called Revealed Comparative Advantages (ARC) (Stellian \& Danna, 2017) was used. The use of the CEPII method is justified by being the most developed to measure comparative advantages through exchanges, through this, 60 groups composed exclusively of agricultural products were analyzed, according to the Standard Classification for International Trade (SITC) among which are:

- 36 groups, whose code starts with 0, made up of live animals and raw or processed food products (except edible oils and water).

- 4 groups, whose code starts with 1, made up of mineral and carbonated waters (code 111), alcoholic beverages (112), tobacco (121) and their derivatives (122). 
- 16 groups, whose code starts with 2, made up of inedible raw materials of animal or vegetable origin (except oils).

- 4 groups, whose code starts with 4 , made up of oils of animal or vegetable origin.

\subsection{Comparative method.}

Through the comparative method (Boddewyn, 1965) an observation was made about the access to agricultural subsidies in Colombia for the benefit of agricultural workers, their access to credit, technical assistance and agricultural insurance compared to the agricultural subsidies in the United States established in the current Farm Bill [2018-2023] (PL115-334, H. Rept. 115-1072), studying Titles I: Commodities-Commodities and Title XI: Crop Insurance.

\subsection{Descriptive Analysis - Investment Budget for the Vulnerable Agricultural Sector.}

For the development of this item, a descriptive analysis was carried out comparing the Law of the Second National Development Plan 2014-2018 (Law 1753 of 2015- All for a new country) of President Juan Manuel Santos and the current Development Plan Law of President Iván Duque 2018-2022 (Law 1955 of 2019- Pact for Colombia, Pact for Equity), an analysis that was carried out evaluating the Pluriannual Investment Plan (PPI) of each period in order to study the investment budget (financial coverage) for the vulnerable agricultural sector.

The observation variables that were taken into account for the analysis were: 1) access to land ownership by agrarian workers 2 ) reduction of rural poverty (monetary and 
multidimensional poverty) and 3) boost competitiveness of the vulnerable rural sector (research and technology transfer for food production), duties of the Colombian State based on articles 64 and 65 of the Constitution.

\subsection{Prospective Approach Method.}

To address the variables of rural poverty, forced displacement, concentration of rural property and agricultural microeconomics in Colombia: the prospective approach was used (Zamora \& Monterroso, 2017) that allows collecting the perspectives of key actors who intervene in processes of recognition of collective rights, but that do not necessarily converge in the same space, including different instances of regional government, native communities, Non-Governmental Organizations (NGOs) and researchers.

\subsubsection{Rural poverty in Colombia.}

\subsubsection{Monetary Poverty.}

Monetary poverty: occurs when the monthly per capita income of a household is below the monetary poverty line (DANE, 2020 b).

\subsubsection{Multidimensional Poverty.}

The Multidimensional Poverty Index -IPM- is composed of 5 dimensions and 15 indicators, as follows: 1. Educational conditions (illiteracy, and low educational achievement). 2. Conditions of childhood and youth (school absence, school delay, access barriers to early childhood care services, and child labor). 3. Work (informal work, and long-term unemployment). 4. Health (without health insurance, and barriers to access to health given a need). 5. Conditions of housing and public services (no access to an 
improved water source, inadequate excreta disposal, inadequate flooring material, inadequate wall material, and critical overcrowding) (DANE, 2020 c).

\subsubsection{Effects of the internal armed conflict-Forced Displacement.}

To develop this section, the figures reported by the World Report on Internal Displacement (2019) were taken into account, as well as the results presented by the Law 1448 of 2011 "By which measures of care, assistance and comprehensive reparation to victims of the internal armed conflict and other provisions are issued", according to the Radiography Report on Land Restitution in Colombia (2019).

\subsubsection{Concentration of rural property in Colombia.}

With the prospective approach method, the figures presented by the Oxfam International Corporation (2017) in its Report Radiography of Inequality, and the Analysis of the Distribution of Rural Property in Colombia-Methodological Proposal (2016) were studied, both investigations are based on the Gini Index updated with the new data from the Third National Agricultural Census-2016 (CNA) (DANE e, 2016,).

\subsubsection{Agricultural Microeconomics.}

Small agriculture contributes a significant percentage in the production of food at the national level, this is found in different investigations, such as The Colombian peasant, between the economic protagonism and the ignorance of society (Forero, 2010) who uses the methodology of static comparative to demonstrate the importance of small agriculture in the country, in addition to the research entitled: The economic efficiency of large, medium and small Colombian agricultural producers, carried out by (Forero et al., 2012). 


\section{Results}

\subsection{Approval of the Free Trade Agreement (FTA) between Colombia and the United States. Concepts of Asymmetries, Equity and Reciprocity.}

The Trade Promotion Agreement between Colombia and the United States entered into force since May 15, 2012 (Ministry of Commerce, Industry and Tourism). Initially, it was mentioned that the treaty implied multiple advantages for Colombia, such as commercial integration with the largest market in the world, permanent preferential access to the United States market and achieving the consolidation of the benefits that at the time were granted by the ATPDEA (Andean Trade Preference Act), in order to turn Colombia into an export platform and an attractive pole for foreign investment (Organization of American StatesOAS).

The Constitutional Court of Colombia, in its ruling on the enforceability of the treaty, indicated that the recognition of asymmetries in trade liberalization treaties as a result of the level of growth and economic development of each State Party, guaranteed compliance with the mandates of equity and reciprocity in the promotion of economic and commercial integration, which could be contemplated in the progressive elimination of customs duties on goods originating in both countries, taking into account the reduction list in Annex 2.3, which would allow the use of the comparative advantages of each country (Constitutional Court Sentence C-750 of 2008). 


\subsection{Observation on the economic results of the Free Trade Agreement (FTA) between Colombia and the United States in agricultural matters.}

For the entry into force of the treaty in $2012,87.1 \%$ of agricultural products already had a tariff elimination carried out in that year or that would have to be completed no later than in 2017 according to the reduction categories (Annex. 2.3), the remaining 12.9\%, has deductions between 8 to 19 years, being some products benefiting from tariff quotas, having free access in both countries as long as they do not exceed the agreed metric tons, otherwise, they must pay the base tariffs according to Annexes 2.3., until the years established in Appendix I of each country are completed, until the annual limit of the quotas is withdrawn and the tariffs reach zero, resulting in a free exchange of products between both countries (Stellian \& Danna, 2017), as can be seen:

\section{Table 1}

Free trade agreement between Colombia and United States: agricultural products

protected by provisional tariff quotas

\begin{tabular}{|c|c|}
\hline \multicolumn{2}{|c|}{ Product type (in parentheses: year of elimination of the quota and the corresponding tariffs; " 1 " $=2012$ ) } \\
\hline Colombia & United States \\
\hline Food for domestic animals $(8 / 9)$ & - \\
\hline $\begin{array}{l}\text { Meat of bovine animals, of standard quality } \\
\text { Offal of bovine animals (10) }\end{array}$ & Meat of bovine animals * $(10)$ \\
\hline Crude soybean oil (10) & - \\
\hline Glucose (10) & - \\
\hline Dry beans* $(10)$ & - \\
\hline - & Liquid milk and cream (11) \\
\hline \multicolumn{2}{|c|}{ Ice cream (11) } \\
\hline \multicolumn{2}{|c|}{ Butter (11) } \\
\hline Maize and sorghum (12) & - \\
\hline Milk in powder and yoghurt (15) & - \\
\hline \multicolumn{2}{|r|}{ Tobacco (15) } \\
\hline \multicolumn{2}{|c|}{ Cheese and processed dairy products (15) } \\
\hline Birds with finished production cycle* (18) & - \\
\hline Poultry leg quarters* ${ }^{*}(18)$ & - \\
\hline Rice* (19) & - \\
\hline
\end{tabular}

Note: Products marked with an asterisk are subject to special safeguards (see section II). All tariff elimination is implemented in equal annual stages (EAS), except in the following cases (Colombia): dry beans, 33\% tariff reduction in year 1 of the FTA, then elimination in nine EAS (years 2-10); Chicken hindquarters, the base rate is maintained until year 5 (10), then elimination in 13 (8) EAS in years 6-18 (11-18); Rice, the base rate is maintained until year 6, then elimination in 13 EAS (years 7-19).

Source: Stellian \& Danna (2017). 


\subsubsection{Competitiveness of Colombian agricultural products under the FTA.}

When applying the Comparative Advantage Indicator (VCR) on 60 agricultural groups according to the Uniform Classification for International Trade (SITC), it was possible to verify the results reveal sustainable comparative advantages over time for only three of them (category K1), while another four have the potential to have them (category K2). The other groups do not present any advantage or present disadvantages, among this category the groups [061] and [062] (sugar and its derivatives) are excepted, where the limit of the quota assigned to Colombia does not disappear, but the initial 50,000 tons are increased by 750 tons per year and continue to do so once year 15 is over.

However, the United States may at its option limit sugar exports by offering a compensation mechanism in any year (Chapter 2. Art. 2.19), which means that Colombia will not be able to freely access the United States market with one of its main products ${ }^{1}$. (Stellian and Danna, 2017).

1 List of groups studied according to the Standard Classification for International Trade (SITC). K1- [034] Fish, fresh (live or dead), chilled or frozen, [071] Coffee and coffee substitutes, [292] Vegetable products raw.

K2- [037] Fish, crustaceans, molluscs and other aquatic invertebrates, prepared or preserved, [057] Fruits and nuts (except oleaginous nuts, fresh or dried), [61] (E) Sugars, molasses and honey, [062 ] E Confectionery made with sugar.

K3- [011] Bovine meat, fresh, chilled or frozen, [016] Meats and edible meat offals, salted, in brine, dried or smoked; edible meal of meat or meat offal, [023] Butter and other fats and oils derived from milk, [025] Poultry eggs and egg yolks; Egg albumin, [035] * Fish, dried, salted or in brine; smoked fish, [045] Unmilled cereals (except wheat, rice, barley and maize), [046] Semolina and wheat flour and morcajo flour, [047] Other semolina and cereal flours, [072] Cocoa, [075] Spices, [091] Margarine and shortening, [121] Raw tobacco; tobacco residues, [211] Raw hides and skins (except fine hides), [212] Raw raw hides (including heads, tails, feet and other parts or cuts suitable for furskins), except for the hides and skins of the group [211], [231] Natural rubber, balata, gutta-percha, guayule, chicle and natural rubbers and the like, in primary forms (including latex) or in plates, sheets or strips, [245] Firewood (except wood waste) and charcoal [246], Wood chips or particles and wood waste, [247] Wood in the rough or just squared, [248] Wood simply worked and wooden railway sleepers, [261] Silk, [265] * Vegetable textile fibers (except cotton and jute), [268] Wool and other animal hairs (including wool tops), [422] * Fats and fixed oils of vegetable origin, except " soft ".

K4- [001] Live animals not included in chapter [03], [036] Crustaceans, molluscs and aquatic invertebrates, peeled or unpeeled, fresh (live or dead), chilled, frozen, dried, salted or in brine; crustaceans, unpeeled, steamed 


\section{Table 2}

Colombia and the United States: agricultural product groups of the International Standard Classification for International Trade (SITC) classified by category of (dis)advantages

\begin{tabular}{|c|c|c|c|}
\hline Category & Meaning & SITC Groups & TOTAL \\
\hline$K_{1}$ & Time-sustainable comparative advantages & [034] [071] [292] & 3 \\
\hline$K_{2}$ & Potentially time-sustainable comparative advantages & {$[037][057][061](E)[062](E)$} & 4 \\
\hline$K_{3}$ & Weak advantages or disadvantages & 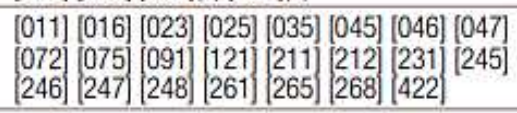 & 23 \\
\hline$K_{4}$ & Weak advantages or disadvantages in fine & {$\left[\begin{array}{l}001 \\
074\end{array}\right]\left[\begin{array}{l}036 \\
111\end{array}\right]\left[\begin{array}{l}043 \\
112\end{array}\right]\left[\begin{array}{l}048 \\
122\end{array}\right]\left[\begin{array}{l}054 \\
291\end{array}\right]\left[\begin{array}{l}058 \\
411\end{array}\right]\left[\begin{array}{l}059 \\
431\end{array}\right]$} & 14 \\
\hline$K_{5}$ & Potentially time-recurrent comparative disadvantages & {$[022](C)[024](C)[056][073][223]$} & 5 \\
\hline$K_{6}$ & Time-recurrent comparative disadvantages & $\begin{array}{l}{[012][017][041][042](C)[044](C)[081]} \\
\text { (C) }[098][222](C)[251][263][421]\end{array}$ & 11 \\
\hline
\end{tabular}

Note: "E" identifes products that the United States continues to protect (sugar and its derivatives). "C" refers to products with comparative disadvantages (K5 and K6) to which Colombia applies a provisional protectionist regime.

Source: Retrieved from Stellian \& Danna (2017).

or steamed in water, [043] Unmilled barley, [048] Cereal preparations and preparations of fruit or vegetable flour or starch, [054] Legumes, fresh, chilled, frozen or simply preserved (including legumes dry); roots, tubers and other edible plant products, n.e.s, fresh or dried, [058] Preserved fruits and fruit preparations (except fruit juices, [059] Fruit juices (including grape must) and legume juices, [074] Tea and mate, [111] Non-alcoholic beverages, n.e.s, [112] Alcoholic beverages, [122]* Manufactured tobacco, [291] Raw animal products, n.e.s, [411] Oils and fats of animal origin, [431] * Fats and oils of animal or vegetable origin, n.e.s.

K5-[022C] Milk, cream and dairy products, except butter and cheese, [024C] Cheese and curd, [056] Legumes, roots and tubers, prepared or preserved, n.e.s, [073] Chocolate and other food preparations that contain cocoa, n.e.s, [223] Whole or broken oil seeds and oleaginous fruits, of a kind used for the extraction of other fixed vegetable oils (including meal from oil seeds or oleaginous fruits, n.e.s).

K6- [012] * Other meats and edible meat offal, fresh, frozen or chilled, [017] Meat and meat offal, prepared or preserved, n.e.s, [041] Wheat (including spelled) and morcajo or calico, not milled, [042] (C) Rice, [044] (C) [044] Corn (except sweet corn), unmilled, [081] (C) Animal feed (except unmilled cereals), [098] Products and preparations edibles, n.e.s, [222] (C) Oil seeds and oleaginous fruits of a kind used for the extraction of fixed "soft" vegetable oils (except flour), [251] Pulp and paper waste, [263] Cotton, [421]*, fixed oils and fats of vegetable origin, "soft".

Source: Stellian \& Danna (2017). United Nations Statistics Division "SITC Rev. 3". Retrived from: http://unstats.un.org/unsd/cr/registry/ regcst.asp?Cl=14\&Lg=3.

Note: The description of the groups with an asterisk is simplified. More details can be seen in the source.

n.e.s: Not specified (or not included) elsewhere. 


\subsubsection{Colombia-United States Trade Balance 2019.}

The trade balance between Colombia and the United States since 2014 has been in deficit, for 2019 it had a deficit of -1,079.7 (millions of FOB dollars), it can also be identified that the mainly exported products to that country during this year were primary, like oil, flowers, coffee and mining, with the agricultural sector having a participation of $21.3 \%$ (DANE, $2020 \mathrm{a})^{2}$.

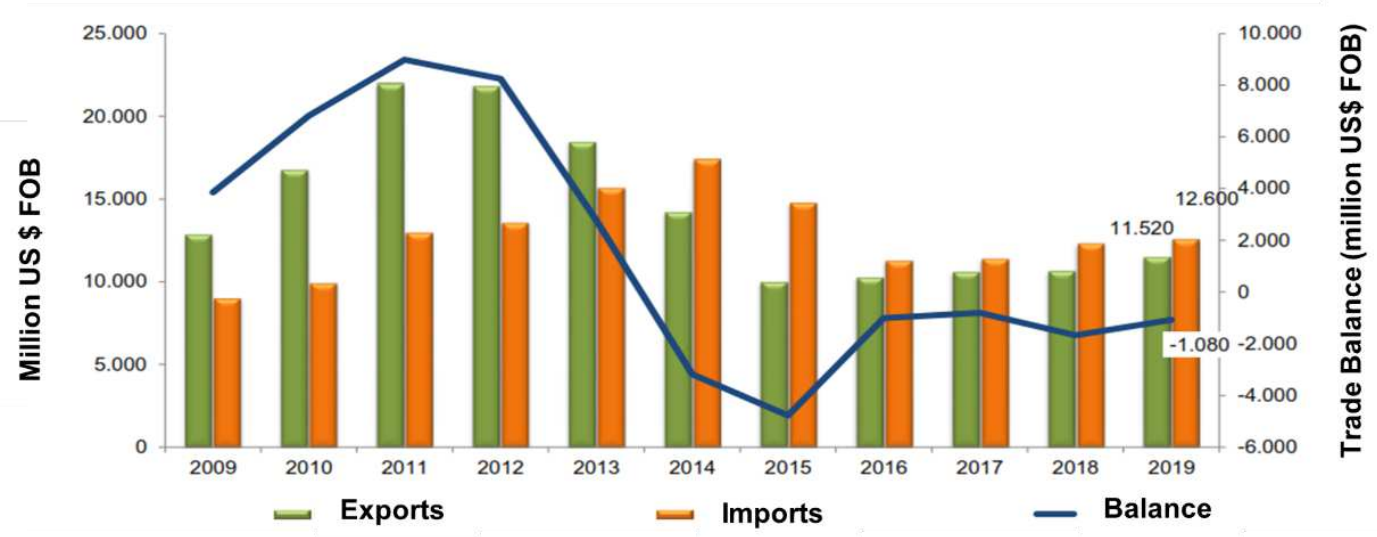

Figure 1. Trade balance (millions of USD \$ FOB) Colombia and the United States 2009-2019. Source: Ministry of Commerce, Industry and Tourism-Mincit (2020).

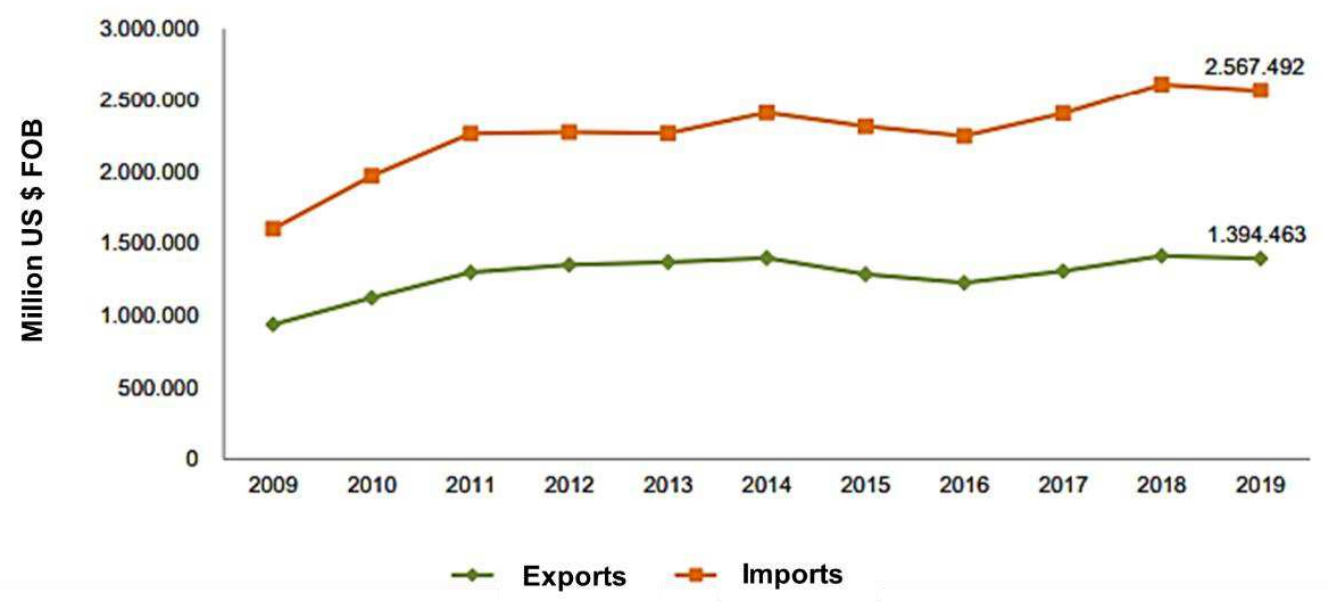

Figure 2. Foreign trade of goods (Millions of USD).

Source: Ministry of Commerce, Industry and Tourism-Mincit (2020).

2 The trade balance between Colombia and the United States, for the years 2014 to 2018, has been in deficit, with the following values: $2014(-3,185.6), 2015$ (-4,773.6), $2016(-1,007.0), 2017$ ( -802.5), 2018 (-1,669.1) (Millions of dollars FOB) (DANE, 2020 a). 


\section{Table 3}

Main sectors 2019. Imports Exports

\begin{tabular}{|c|c|c|}
\hline Exports & $\begin{array}{l}\text { Thousands of } \\
\text { USD }\end{array}$ & Part. $\%$ \\
\hline Petroleum & 4.898 .843 & 42,5 \\
\hline Derivatives of oil & 1.542 .642 & 13,4 \\
\hline Flowers & 1.149 .308 & 10,0 \\
\hline Coffee & 987.726 & 8,6 \\
\hline Other miners & 539.502 & 4,7 \\
\hline Rest & 2.402 .097 & 20,9 \\
\hline Total exported to the United States & 11.520 .119 & 100,0 \\
\hline Imports & $\begin{array}{l}\text { Thousands of } \\
\text { USD }\end{array}$ & Part. \% \\
\hline Derivatives of oil & 3.289 .176 & 24,8 \\
\hline Basic Chemistry & 2.911 .127 & 21,9 \\
\hline Machinery and equipment & 2.353 .870 & 17,7 \\
\hline Agricultural strips & 1.635 .535 & 12,3 \\
\hline Agroindustrial strips & 590.263 & 4,4 \\
\hline Rest & 2.496 .870 & 18,8 \\
\hline $\begin{array}{l}\text { Total imported from the United States } \\
\text { (CIF) }\end{array}$ & 13.276 .840 & 100,0 \\
\hline $\begin{array}{l}\text { Imports (FOB) } \\
\text { Trade Balance (FOB) }\end{array}$ & \multicolumn{2}{|c|}{$\begin{array}{c}12.599 .791 \\
-1.079672\end{array}$} \\
\hline
\end{tabular}

Source: Ministry of Commerce, Industry and Tourism-Mincit (2020).

\subsubsection{Agricultural subsidies in Colombia vs. agricultural subsidies in the United}

\section{States.}

\subsubsection{Agricultural insurance in Colombia.}

The agricultural insurance market has a very low historical performance; Until 2006, the total area covered did not exceed 5,000 hectares, which represents less than 0.1 percent of the cultivated area of the country. It is interesting to note that in 2010 the insured area corresponded to approximately $1 \%$ of the total cultivated area and in 2015 this proportion reached $2 \%$ with 186,884 hectares (Figueroa, 2017).

For 2019, approximately 175,000 hectares were insured, with an incentive payment worth $\$ 33,809$ million pesos equivalent to US $\$ 9,286,658.45$, without a significant increase at the national level, since the area with agricultural use in Colombia is of 7.1 million hectares (CNA, 2016, p. 53), on the other hand, the Incentive for Agricultural 
Insurance, was granted $30 \%$ for sugar cane, $22 \%$ for forestry, $15 \%$ for bananas, $13 \%$ for rice, $9 \%$ for corn and $5 \%$ for coffee, showing a limitation in the coverage of insured products (Fund for the Financing of the Agricultural Sector-FINAGRO, 2019).

\subsubsection{Number of producers as natural persons, by holding agricultural insurance -} 2019.

For the second half of 2019, only 1,480 of the producers with the legal status of natural person had agricultural insurance in the Agricultural Production Unit (UPA), 3,320 had agricultural insurance in another UPA, however, 1,922,944 of producers declare that they do not have agricultural insurance in the agricultural production unit.

\section{Table 4}

Number of producers in the condition of natural persons, by holding agricultural insurance National total Second semester 2019

\begin{tabular}{|c|c|c|c|c|c|c|c|c|c|c|c|c|c|c|}
\hline \multicolumn{3}{|c|}{ Total producers } & \multicolumn{3}{|c|}{$\begin{array}{l}\text { Counts with agricultural } \\
\text { insurance }\end{array}$} & \multicolumn{3}{|c|}{$\begin{array}{l}\text { Counts with agricultural } \\
\text { insurance in other UPA }\end{array}$} & \multicolumn{3}{|c|}{$\begin{array}{l}\text { Does not have } \\
\text { agricultural insurance }\end{array}$} & \multicolumn{3}{|c|}{ Does not inform } \\
\hline Producers & Cve & IC95\% \pm & Producers & Cve & IC95\% \pm & Producers & Cve & IC95\%士 & Producers & Cre & IC95\%士 & Producers & Cre & IC95\%士 \\
\hline 2.033 .967 & 1,4 & 57.369 & 11480 & 10,8 & 2.420 & 3.320 & 17,3 & 1.123 & 1.922 .944 & 1,5 & 57.757 & 96.854 & 5,6 & 10.575 \\
\hline
\end{tabular}

Source: DANE. National Agricultural Survey -ENA (2020).

\subsubsection{Access to machinery, technical assistance and credit.}

According to the CNA National Agricultural Census (2016), only in 16.4\% of the Agricultural Production Units (UPAs) in Colombia, the producers declared having machinery for the development of their agricultural activities, while $83.6 \%$ do not have (CNA, p. 102), with respect to technical assistance, only $16.5 \%$ received it and $83.5 \%$ did 
not have access to it (CNA, p. 109), in relation to access to agricultural credit, only the $10.7 \%$ requested it while $89.3 \%$ did not (ibid, p. 116).

During the first semester of 2019, of the 2,020,662 Agricultural Production Units - UPA, $385,293(19.1 \%)$ used machinery for the tasks associated with the different agronomic phases of the crops; while 1,630,994 (80.7\%) UPA do not use machinery (heavy or light). $0.2 \%$ of the remaining UPA did not report (ENA, 2020).

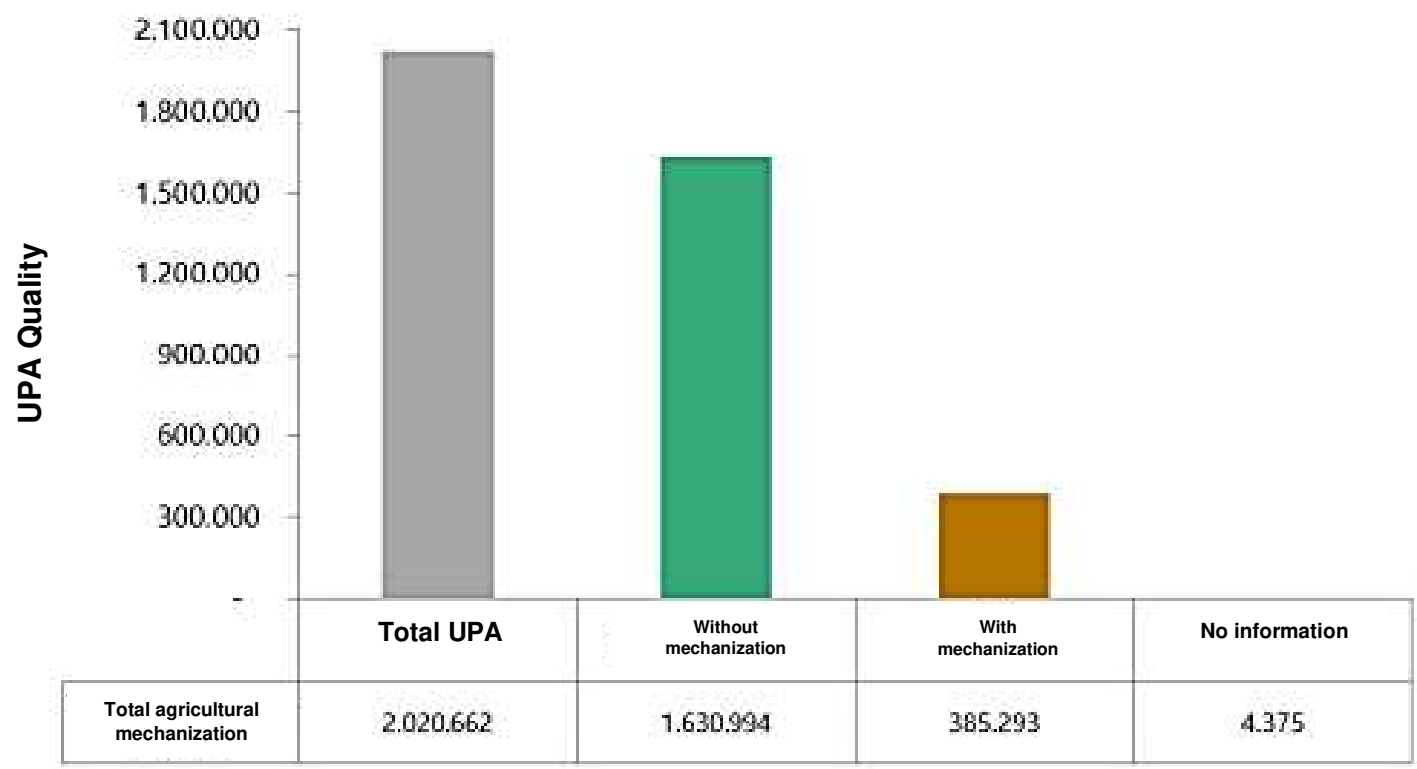

Figure 3. Amount of UPA, by use of agricultural machinery in the different agronomic phases of the crops. National total. First semester 2019.

Source: DANE, National Agricultural Survey ENA (2020)

\subsubsection{The Agricultural Improvement Act of 2018. The American Farm Bill.}

The agricultural bill (PL115-334, H. Rept. 115-1072) was approved for an amount of US $\$ 867$ billion, whose provisions expire in 2023, contains 12 titles that include income support for products basic, agricultural credit, trade, agricultural conservation, research, rural development, energy, and national and foreign food programs, among other programs (Congressional Research Service, 2019). 


\subsubsection{Title I: Basic Products-Commodities.}

The commodity title authorizes support programs for covered dairy, sugar, and commodities, including major crops of grains, oilseeds, and legumes, as well as agricultural disaster assistance. Major field crop programs include Loss of Price Hedge (PLC), Agricultural Risk Hedge (ARC) and Marketing Assistance Loans (MAL).

\subsubsection{Title XI: Crop insurance.}

The title of Crop Insurance modifies the Federal Law of Crop Insurance with permanent authorization. The federal crop insurance program offers subsidized policies to farmers to protect against losses in yield, crop income, or farm-wide income.

\section{Table 5}

Projected Outlays of the 2018 Farm Bill Since Enactment (millions of dollars, five-year totals, mandatory spending)

\begin{tabular}{|c|c|c|c|c|}
\hline \multirow[b]{2}{*}{ Selected farm bill titles } & \multicolumn{2}{|c|}{ At enactment, December 2018} & \multicolumn{2}{|c|}{ Most recently, May 2019} \\
\hline & $\begin{array}{l}\text { Projection for } \\
\text { FY2019-FY2023 }\end{array}$ & Share & $\begin{array}{l}\text { Projection for } \\
\text { FY2019-FY2023 }\end{array}$ & $\begin{array}{l}\text { Change since } \\
\text { enactment }\end{array}$ \\
\hline Nutrition & 326,020 & $76.1 \%$ & 321,405 & $-4,615$ \\
\hline Crop Insurance & 38,010 & $8.9 \%$ & 40,882 & $+2,872$ \\
\hline Commodities and Disaster & 31,440 & $7.3 \%$ & 26,763 & $-4,677$ \\
\hline Conservation & 29,270 & $6.8 \%$ & 28,477 & -793 \\
\hline Subtotal, four largest titles & 424,740 & $99.2 \%$ & 417,527 & $-7,213$ \\
\hline Total, 12 titles (see Table I) & 428,282 & $100.0 \%$ & na & na \\
\hline
\end{tabular}

Note: CRS, using CBO data. See Table 1 and based on CBO data in "Details About Baseline Projections for Selected Programs," May 2019. Notes: "na" indicates that sufficient detail is not available to compile data for all titles in non-farm-bill years.

Source: Congressional Research Service (2019). 


\section{Table 6}

Budget for the 2018 Farm Bill

(millions of dollars, five-and 10-year totals, mandatory spending)

\begin{tabular}{|c|c|c|c|c|c|c|}
\hline \multirow[b]{2}{*}{ Farm bill titles } & \multicolumn{3}{|c|}{ Five years (FY2019-FY2023) } & \multicolumn{3}{|c|}{10 years (FY2019-FY2028) } \\
\hline & $\begin{array}{c}\text { CВO } \\
\text { baselline } \\
\text { April } 2018\end{array}$ & $\begin{array}{l}\text { Score of } \\
2018 \text { farm } \\
\text { bill }\end{array}$ & $\begin{array}{l}\text { Projected } \\
\text { outlays at } \\
\text { enactment }\end{array}$ & $\begin{array}{c}\text { CBO } \\
\text { baseline } \\
\text { April } 2018\end{array}$ & $\begin{array}{l}\text { Score of } \\
2018 \text { farm } \\
\text { bill }\end{array}$ & $\begin{array}{l}\text { Projected } \\
\text { ourtlays at } \\
\text { enactment }\end{array}$ \\
\hline Commodities & 31,340 & +101 & 31,440 & 61,151 & +263 & 61,414 \\
\hline Conservation & 28,715 & +555 & 29,270 & 59,754 & 6 & 59,748 \\
\hline Trade & 1,809 & +235 & 2,044 & 3,624 & +470 & 4,094 \\
\hline Nutrition & 325,922 & +98 & 326,020 & 663,828 & +0 & 663,828 \\
\hline Credit & $-2,205$ & 40 & $-2,205$ & $-4,558$ & 40 & $-4,558$ \\
\hline Rural Development & 98 & -530 & -432 & 168 & $-2,530$ & $-2,362$ \\
\hline Research & 329 & +365 & 694 & 604 & +615 & 1,219 \\
\hline Forestry & 5 & 40 & $\mathbf{5}$ & 10 & 40 & 10 \\
\hline Energy & 362 & +109 & 471 & 612 & +125 & 737 \\
\hline Horticulture & 772 & +250 & 1,022 & 1,547 & +500 & 2,047 \\
\hline Crop Insurance & 38,057 & -47 & 38,010 & 78,037 & -104 & 77,933 \\
\hline Miscellaneous & 1,259 & 4685 & 1,944 & 2,423 & +738 & 3,161 \\
\hline Subtotal & 426,462 & $+1,820$ & 428,282 & 867,200 & +70 & 867,270 \\
\hline - Increase revenue & - & +35 & 35 & - & +70 & 70 \\
\hline Total & 426,462 & $+1,785$ & 428,247 & 867,200 & 40 & 867,200 \\
\hline
\end{tabular}

Note: CRS. Compiled from the CBO Baseline by Title (unpublished; April 2018); and CBO cost estimate of the conference agreement for H.R. 2, December 11, 2018. Baseline for the Credit title is negative because of receipts to the Farm Credit System Insurance Fund. Baseline for the Rural Development "cushion of credit" is accounted for outside of the farm bill.

Source: Congressional Research Service (2019).

\subsection{The investment budget for the vulnerable agricultural sector. Periods (2014-} 2018) (2018-2022)

\subsubsection{Law 1753 of 2015 "By which the National Development Plan is issued}

2014-2018: All for a new country”.

In the 2015-2018 Pluriannual Investment and Budgeting Plan, a value of seven hundred three point nine (\$703.9) billion pesos was estimated, earmarking for the Countryside Transformation strategy, 49,271,574 billion pesos, which made up only $7 \%$ of the MultiYear Plan. The total resources assigned for each objective corresponding to the 
Transformation of the Field strategy in millions of pesos for 2014 are presented below (Article. 5).

\section{Table 7}

Transformation of the field. Investment Plan 2015-2018. Figures in millions of pesos in 2014

\begin{tabular}{|l|r|}
\hline Strategy-Objective & \multicolumn{1}{|c|}{ Total } \\
\hline Field transformation & 49.271 .574 \\
\hline Reducing poverty and expanding the rural middle class & 3.129 .143 \\
Boost rural competitiveness & 42.784 .512 \\
Institutional strengthening of the territorial presence & 241.057 \\
Land use planning and rural access & 853.745 \\
Close the urban-rural gap and lay the foundations for social mobility & 2.263 .116 \\
\hline
\end{tabular}

Source: Law 1753 of 2015 "By which the National Development Plan is issued 2014-2018: All for a new country".

\subsubsection{Law 1955 of May 25, 2019 “By which the 2018-2022 National Development Plan is issued. "Pact for Colombia, Pact for Equity".}

The National Public Investment Plan (PPI) 2019-2022 was estimated at a value of one thousand ninety-six, point one $(\$ 1,096.1)$ billion of 2018 pesos, which includes the transversal component, Multi-year Investment Plan for Peace that was estimated at a value of thirty-seven point one (\$37.1) billion pesos. In this period, the budget for the agriculture and rural development sector was 23.2 billion pesos equivalent to US \$ 6,367,676.49 (PPI, p. 8), however, the "Field with Progress" strategy has \$12,054 billion pesos (PPI 20182022, p. 14).

In the Pluriannual Investment Plan for Peace, an amount of 2,016.2 billion pesos was allocated for the line "Countryside with progress: an alliance to boost development and 
productivity in rural Colombia" (p. 36), for a total of 14,070,2 billion pesos for the National Development Plan in force. The difference between both Investment Plans is considerable.

\subsection{Brief description of the agricultural panorama in Colombia: Rural poverty, concentration of rural property and agricultural microeconomics in Colombia.}

\subsubsection{Monetary Poverty.}

In 2019 , the percentage of people classified as poor with respect to the total national population was $35.7 \%$. In the municipal capitals this proportion was $32.3 \%$ in the populated centers and dispersed rural $47.5 \%$, thus, the incidence of poverty in the populated centers and dispersed rural is equivalent to 1.5 times the incidence in the municipal capitals.

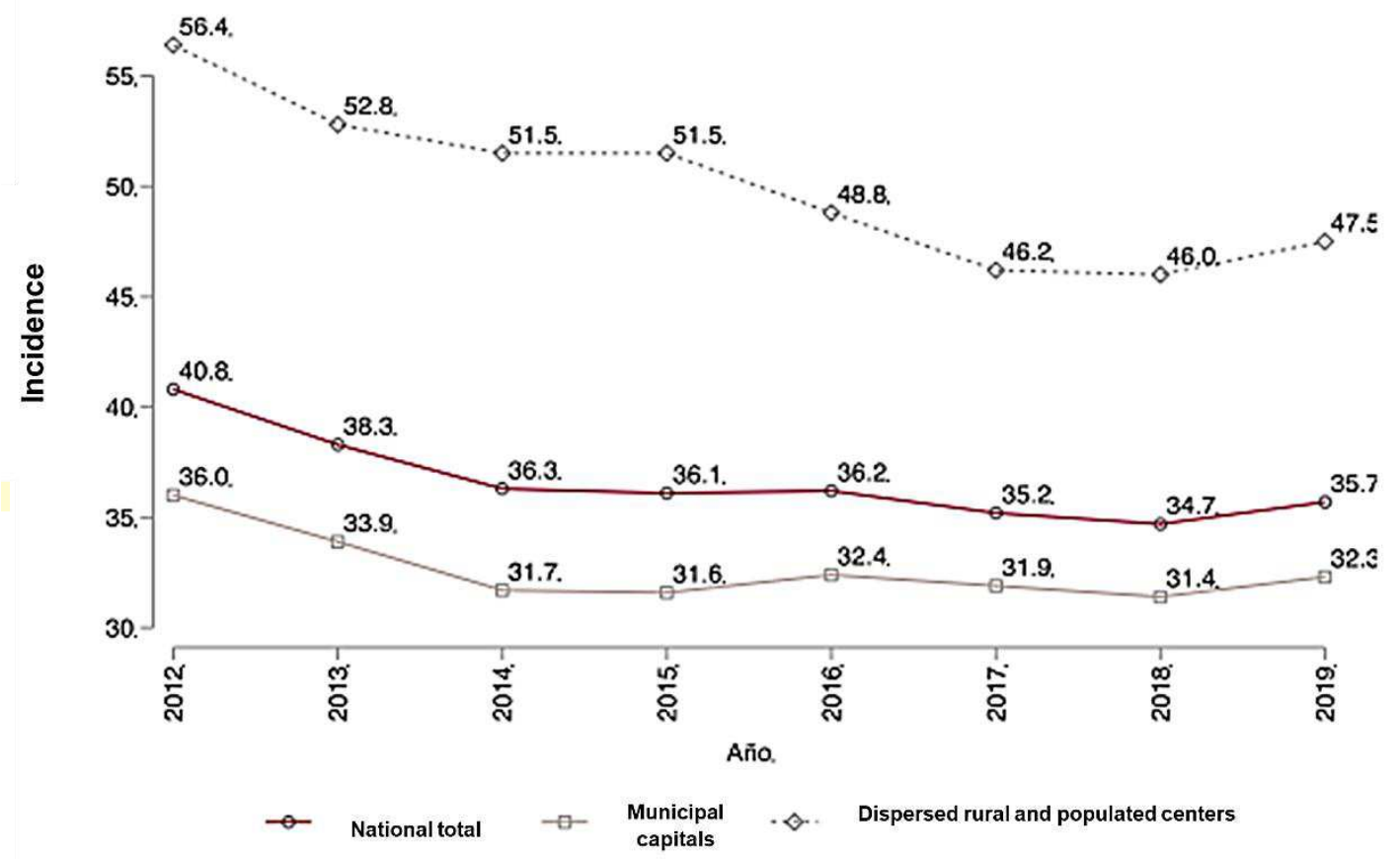

Figure 4. Incidence of Monetary Poverty (percentage). National total, headwaters and populated centers and dispersed rural. 2012-2019

Source: National Administrative Department of Statistics-DANE (2020b). 


\subsubsection{Multidimensional Poverty Index.}

In 2019 , multidimensional poverty in the municipal capitals of the country was $12.3 \%$ (0.9 percentage points less than in 2018), and in the populated and dispersed rural centers it was 34.5\% (4.1 percentage points below the one registered in 2018) (DANE, $2020 \mathrm{c}$ ).

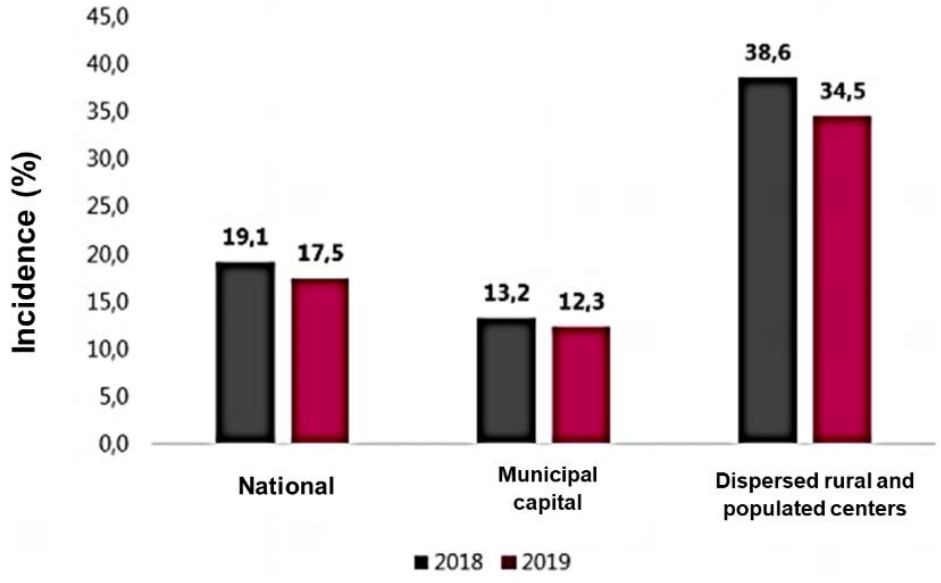

Figure 5. Incidence of multidimensional poverty- Major domains 2018 and 2019 Source: National Administrative Department of Statistics -DANE (2020c).

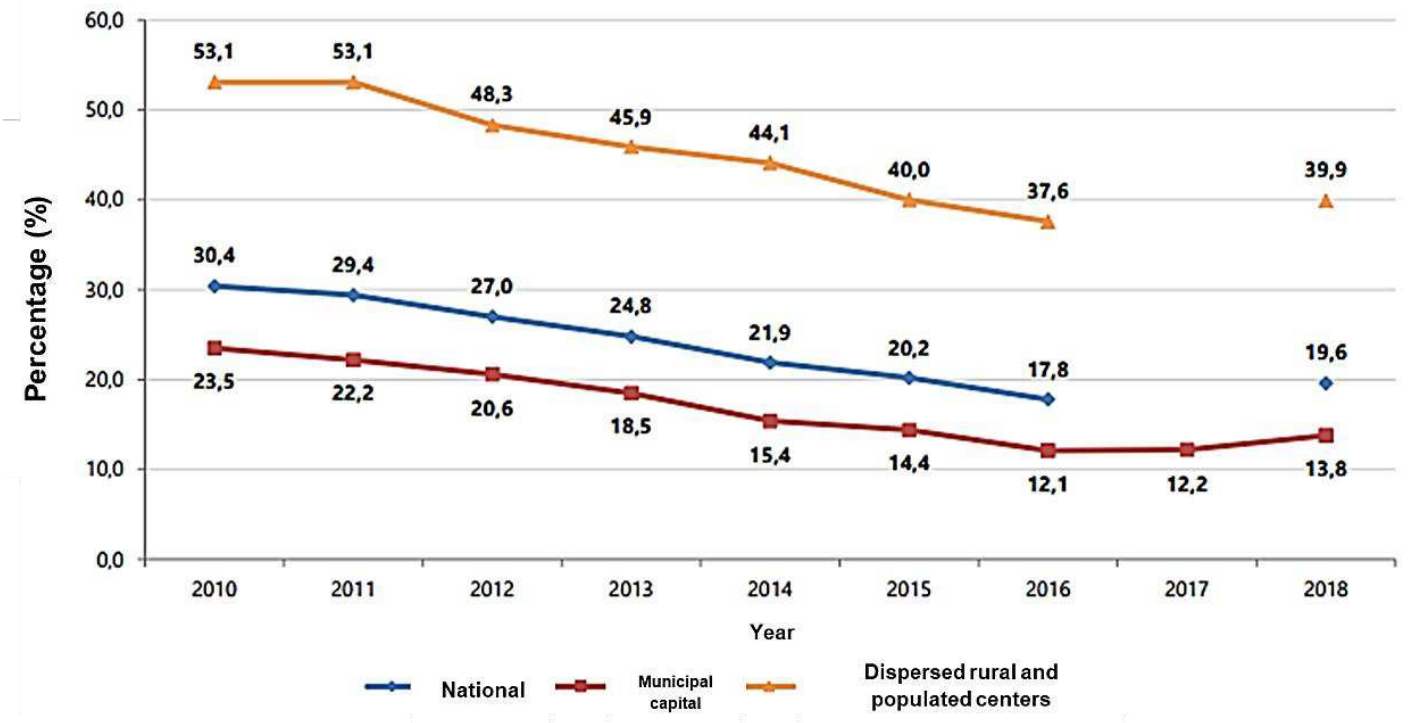

Figure 6: Multidimensional Poverty Results. Quality of Life Survey ECV 2010-2018. The estimates were made using the expansion factors of the 2005 Census.

Source: Administrative Department of Statistics-DANE. (2020c). Press conference presentation. 
In terms of multidimensional poverty, the highest percentages for 2019 , in the Populated and Rural Dispersed Centers are represented by the variables of low educational achievement with $77.6 \%$, school lag with $30.9 \%$, without access to an improved water source with $41.2 \%$ and informal work with $90.6 \%$ :

\section{Table 8}

Percentage of private households by indicator-National total, capital cities, populated centers and dispersed rural areas. 2018-2019.

\begin{tabular}{|c|c|c|c|c|c|c|c|c|c|c|c|c|}
\hline $\begin{array}{l}\text { Figures in } \\
\text { percentage }\end{array}$ & \multicolumn{2}{|c|}{$\begin{array}{l}\text { National } \\
\text { total }\end{array}$} & \multirow[t]{2}{*}{$\begin{array}{c}\text { Change } \\
2018- \\
2019\end{array}$} & & \multicolumn{2}{|c|}{$\begin{array}{l}\text { Municipal } \\
\text { capital }\end{array}$} & \multirow[t]{2}{*}{$\begin{array}{l}\text { Change } \\
2018- \\
2019\end{array}$} & & \multicolumn{2}{|c|}{$\begin{array}{l}\text { Dispersed } \\
\text { rural and } \\
\text { populated } \\
\text { centers }\end{array}$} & \multirow[t]{2}{*}{$\begin{array}{c}\text { Change } \\
2018- \\
2019\end{array}$} & \\
\hline Variable & 2018 & 2019 & & & 2018 & 2019 & & & 2018 & 2019 & & \\
\hline Illiteracy & 10,0 & 9,3 & $-0,7^{*}$ & y & 6,3 & 6,0 & $-0,3$ & \pm & 22,6 & 20,5 & $-2,1^{*}$ & $t$ \\
\hline $\begin{array}{l}\text { Low educatic } \\
\text { achievement }\end{array}$ & 44,5 & 44,0 & $-0,5$ & 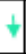 & 34,4 & 34,1 & $-0,3$ & $\downarrow$ & 78,8 & 77,6 & $-1,2^{*}$ & $\downarrow$ \\
\hline $\begin{array}{l}\text { Barriers to early } \\
\text { childhood care } \\
\text { services }\end{array}$ & 8,3 & 7,9 & $-0,4^{*}$ & 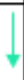 & 8,6 & 8,3 & $-0,3$ & , & 7,1 & 6,6 & $-0,5$ & \\
\hline $\begin{array}{l}\text { Barriers to } \\
\text { to health }\end{array}$ & 6,2 & 5,5 & $-0,7$ & 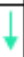 & 5,7 & 5,6 & $-0,1$ & 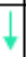 & 7,8 & 5,4 & $-2,4^{*}$ & \\
\hline $\begin{array}{l}\text { Long-term } \\
\text { unemployment }\end{array}$ & 12,1 & 12,4 & 0,3 & † & 12,7 & 12,9 & 0,2 & $\uparrow$ & 10,0 & 11,0 & 1,0 & $\uparrow$ \\
\hline $\begin{array}{l}\text { Critical } \\
\text { overcrowding }\end{array}$ & 8,3 & 8,6 & 0,3 & 4 & 8,4 & 8,9 & 0,5 & $\uparrow$ & 8,1 & 7,5 & $-0,6$ & $\neq$ \\
\hline $\begin{array}{l}\text { Inadequate } \\
\text { disposal of } \\
\text { excreta }\end{array}$ & 11,6 & 11,0 & $-0,6$ & & 7,4 & 7,2 & $-0,2$ & & 26,0 & 23,7 & $-2,3^{*}$ & \\
\hline School absence & 3,1 & 2,7 & $-0,4^{*}$ & it & 2,5 & 2,1 & $-0,4^{*}$ & 1 & 5,3 & 4,6 & $-0,7^{*}$ & $\$$ \\
\hline $\begin{array}{l}\text { Unsuitable } \\
\text { exterior wall } \\
\text { material }\end{array}$ & 2,7 & 2,6 & $-0,1$ & & 2,9 & 2,7 & $-0,2$ & & 2,0 & 2,7 & $0,6^{*}$ & \\
\hline $\begin{array}{l}\text { Unsuitable } \\
\text { flooring material }\end{array}$ & 6,2 & 6,4 & 0,2 & 1 & 1,9 & 2,0 & 0,1 & $\uparrow$ & 20,7 & 21,4 & 0,7 & $\uparrow$ \\
\hline Scho & 27,4 & 25,8 & $-1,6^{*}$ & & 25,5 & 24,3 & $-1,2^{*}$ & \pm & 33,9 & 30,9 & $-3,0$ & \pm \\
\hline $\begin{array}{l}\text { No access to } \\
\text { improved water } \\
\text { source }\end{array}$ & 11,7 & 11,5 & $-0,2$ & & 2,9 & 2,8 & $-0,1$ & & 41,5 & 41,2 & $-0,3$ & \\
\hline $\begin{array}{l}\text { No health } \\
\text { insurance }\end{array}$ & 11,0 & 11,3 & 0,3 & I & 11,1 & 11,9 & 0,8 & $\uparrow$ & 10,6 & 9,5 & $-1,1^{*}$ & $\uparrow$ \\
\hline Child labor & 2,0 & 1,7 & $-0,3^{*}$ & & 1,4 & 1,2 & $-0,2$ & 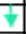 & 4,2 & 3,4 & $-0,8^{*}$ & $\nabla$ \\
\hline Informal work & 72.7 & 72.9 & 0,2 & & 67,5 & 67.7 & 0,2 & 4 & 90,5 & 90.6 & 0.1 & 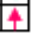 \\
\hline
\end{tabular}

Note: The abbreviations $\mathrm{CP}$ and RD correspond to populated centers and dispersed rural.

Source: National Administrative Department of Statistics -DANE (2020c).

\subsubsection{Colombia: The Latin American nation with the highest concentration of land}

According to the Radiography Report of Inequality prepared by Oxfam International (2017), Colombia is ranked first in the ranking of inequality in the distribution of land, followed by Peru, Chile and Paraguay, in addition to adding that in Colombia, $1 \%$ of the 
largest farms manage more than $80 \%$ of the land, while the remaining $99 \%$ distribute less than $20 \%$ of it (Oxfam, 2017 p. 13).

\subsubsection{Gini index of the area of private rural property owners with agricultural destinations in Colombia.}

According to the Analysis of Distribution of Property in Colombia. Methodological Proposal (2016), in accordance with the Agustin Codazzi Geographical Institute and the Antioquia, Bogotá and Medellín (2014) cadasters, the indicator of 0.8789 for Colombia was established, finding this value in the range of 0.6 to 1 , which "corresponds to a high inequality in the distribution of property, in this case of land area of rural properties" ( $\mathrm{p}$. $115)$.

The above means that instead of having an equal distribution where $10 \%$ of the owners have $10 \%$ of the area, it can be observed that between $80 \%$ and $90 \%$ of the owners barely reach around $10 \%$ of the area, which means that the remaining $90 \%$ of the area corresponds to $10 \%$ of the owners with the largest areas of land.

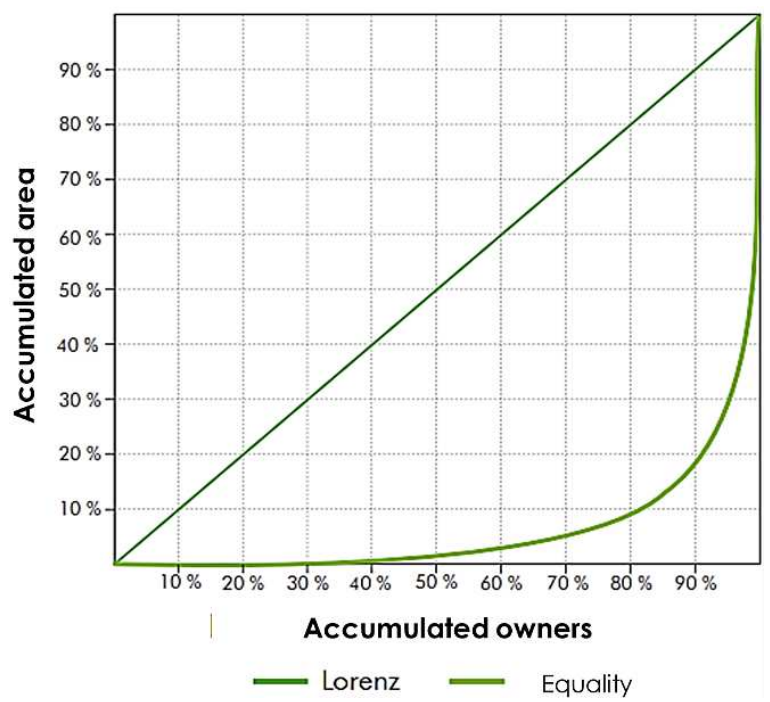

Figure 7. Colombia: Lorenz curve for the area of owners of private rural properties with agricultural destination (2014)

Source: Ministry of Agriculture and Rural Development, Rural Agricultural Planning Unit -UPRA (2016). 


\subsubsection{Accumulation of Agricultural Production Units (UPA).}

The classification by size of the Agricultural Production Units (UPA) shows that $70.4 \%$ of the UPA $(1,669,287$ units) have less than 5 hectares and occupy $2.0 \%(2,160,347$ ha) of the rural area census dispersed; while $0.2 \%$ of the UPAs have 1,000 hectares or more and occupy $73.8 \%$ of the dispersed rural area surveyed. (National Agricultural Census, p. 67)

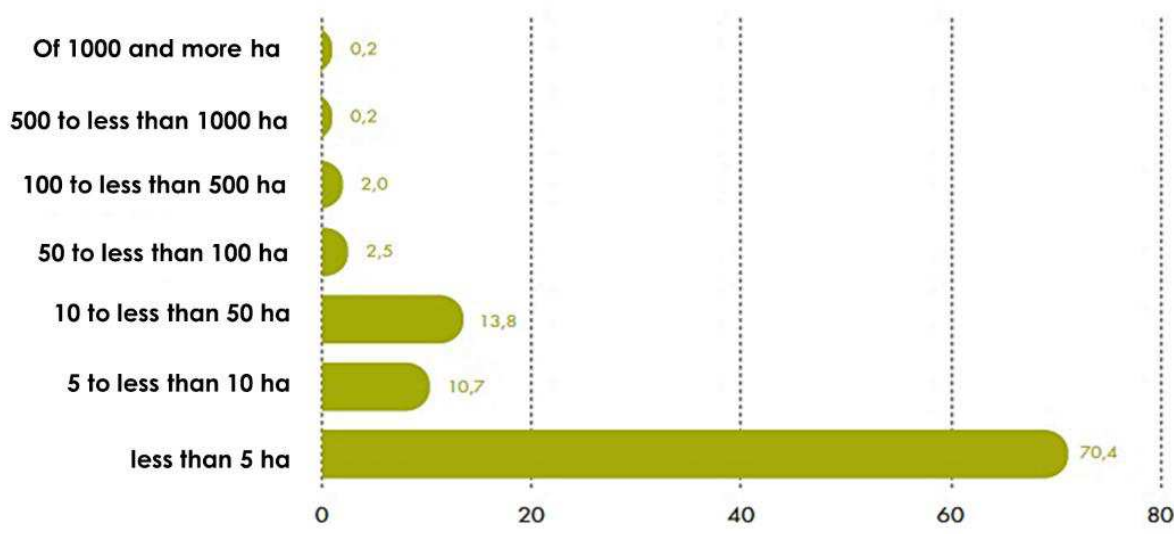

Figure 8. Distribution (\%) of the number of UPAs in the dispersed rural area surveyed, according to size (ha) Source: National Administrative Department of Statistics-DANE (2016 e).

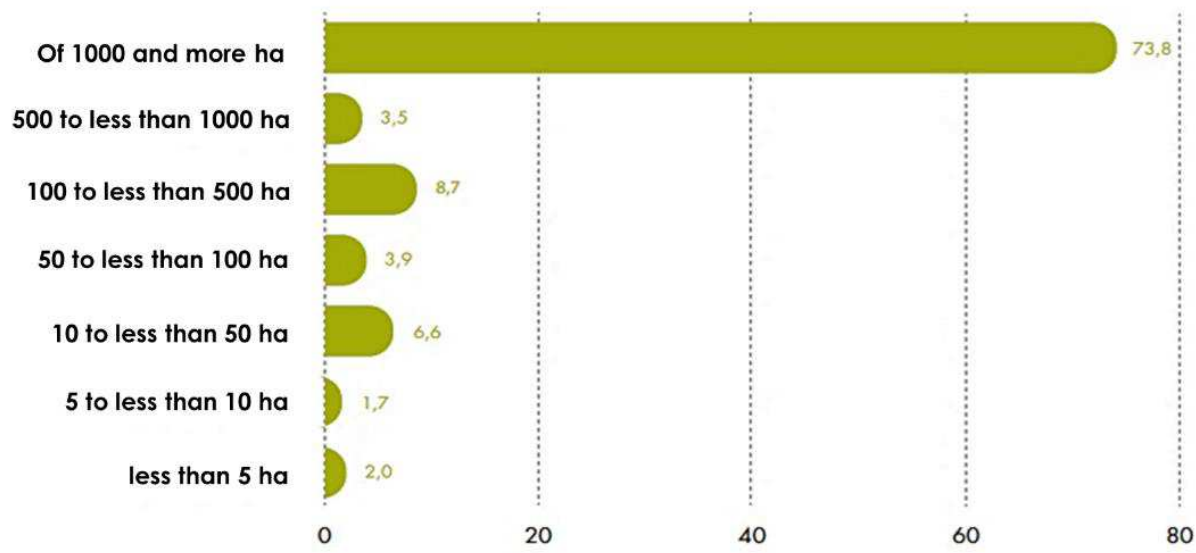

Figure 9. Distribution (\%) of the number of UPAs in the dispersed rural area surveyed, according to size (ha) Source: National Administrative Department of Statistics-DANE (2016 e). 


\subsubsection{Prevalence of agroindustrial crops in Colombia. Results of the National}

Agricultural Survey (ENA-2020).

The total area planted in the country during 2019 was 5,311,977 hectares, finding that, agroindustrial crops presented the highest participation with $41.2 \%$ and an area of $2,186,389$ hectares, followed by cereals that represented the $18.5 \%$ with an area of 984,859 hectares and forest plantations with $13.5 \%$ and an area of 716,501 hectares. Tubers and banana had a participation of $10.8 \%$ and an area of 574,770 hectares, followed by fruit trees with $9.5 \%$ and an area of 505,164 hectares, the group of vegetables, vegetables and legumes with 5.4\% and an area of 288,212 hectares and the other cultivated areas with $1.1 \%$ and an area of 56,083 hectares (ENA, 2020).

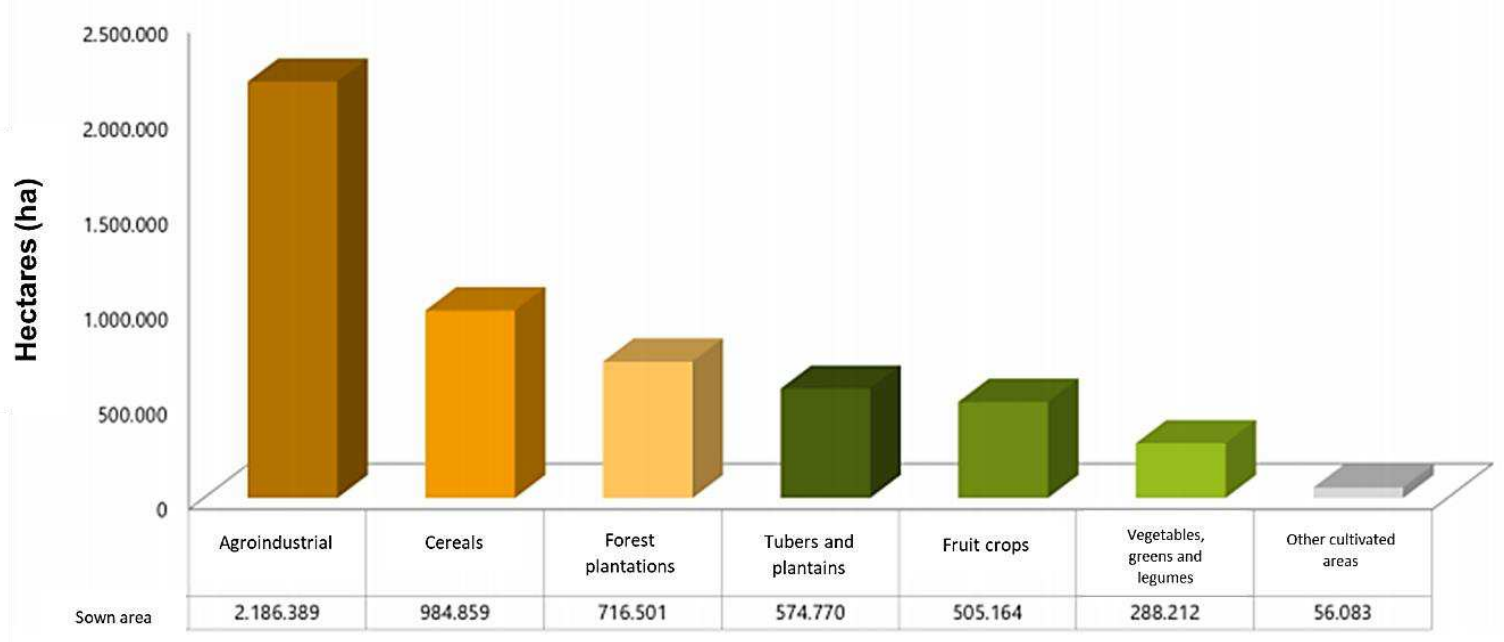

Figure 10. Sown area or planted by crop groups (hectares) National total. 2019 Source: National Administrative Department of Statistics-DANE (2020d).

\subsubsection{Figures of forced displacement and land restitution in Colombia.}

According to the World Report on Internal Displacement (2019), Colombia ranks second out of the ten countries with the highest number of people displaced by conflict and 
violence at the end of 2018, with 5.1 million people living in a situation of internal displacement (IDMC, 2019 p. 48).

On the other hand, Law 1448 of 2011 “By which measures of care, assistance and comprehensive reparation are issued to the victims of the internal armed conflict and other provisions are issued", in its article 208 established that it would be valid for ten (10 ) years, this is until June 10, 2021 and for 2019, restitution sentences were achieved in less than 350 thousand hectares when the problem of dispossession was initially calculated at 6 million hectares, in the same sense, the Restitution Unit de Tierras, has denied more than $63 \%$ of the victims access to the judicial restitution procedure (Colombian Commission of Jurists, 2019, p. 12).

By 2018 , the restitution order of 4,239 properties plus six ethnic territories had been reached. In other words, 216,000 hectares have been restored so far throughout the country. In judicial offices there are requests for another 600,000 hectares (El Tiempo, 2018) ${ }^{3}$.

\subsection{Agricultural microeconomics in Colombia.}

For the previous reasons, the question of the efficiency of small farmers in comparison with medium and large agricultural entrepreneurs is raised, research that was carried out by (Forero et al, 2012) using as indicators of economic efficiency the concepts of technical profitability, net profitability and technical efficiency in the use of land.

\footnotetext{
${ }^{3}$ See the special report prepared by the newspaper El Tiempo "We still haven't reached the promised land: balance of land restitution in Colombia" available at https://www.eltiempo.com/datos/balance-de-larestitucion- of-lands-in-colomba-119708
} 
And the answer, after analyzing the information collected in twelve areas of the country, was that, on average, both large and small producers present relatively similar economic efficiency indicators.

\section{Table 9}

Technical profitability, net profitability and technical efficiency in the use of the land, for family producers for ten areas. 2012. (Conventional method)

\begin{tabular}{|c|c|c|c|c|}
\hline & $\begin{array}{l}\text { Number of } \\
\text { producers }\end{array}$ & Net profitability & $\begin{array}{c}\text { Technical } \\
\text { profitability }\end{array}$ & $\begin{array}{l}\text { Technical } \\
\text { efficiency of } \\
\text { land use. } \\
\text { Pesos per } \\
\text { hectare }\end{array}$ \\
\hline \multirow{2}{*}{ Family } & \multirow{2}{*}{289} & $45 \%$ & $48 \%$ & 1.830 .080 \\
\hline & & $9 \%$ & $9 \%$ & $15 \%$ \\
\hline \multirow{2}{*}{ Large } & \multirow{2}{*}{116} & $48 \%$ & $51 \%$ & 2.803 .847 \\
\hline & & $13 \%$ & $13 \%$ & $14 \%$ \\
\hline \multirow{2}{*}{ Medium } & \multirow{2}{*}{249} & $48 \%$ & $51 \%$ & 2.551 .618 \\
\hline & & $10 \%$ & $10 \%$ & $12 \%$ \\
\hline \multirow{2}{*}{$\begin{array}{l}\text { Small non- } \\
\text { family } \\
\text { producers }\end{array}$} & \multirow[b]{2}{*}{743} & $55 \%$ & $58 \%$ & 3.026 .582 \\
\hline & & $5 \%$ & $5 \%$ & $6 \%$ \\
\hline \multirow{2}{*}{ Total } & \multirow{2}{*}{1388} & $51 \%$ & $54 \%$ & 2.673 .634 \\
\hline & & $4 \%$ & $4 \%$ & $5 \%$ \\
\hline \multicolumn{2}{|c|}{ Differences } & ${ }^{\star \star} \mathrm{Fp}$ & ${ }^{\star \star} \mathrm{Fp}$ & $\begin{array}{l}{ }^{* *} \mathrm{Fp}{ }^{* \star \star} \mathrm{fm} \\
\mathrm{Fpp}\end{array}$ \\
\hline
\end{tabular}

Coefficients of variation (c.v.c) in italics

Note: LM significant differences between large and medium producers. LS significant differences between large and small producers. MS significant differences between medium and small producers. FS significant differences between familiar and small non-family producers $* * *$ at $1 \%$ (extremely high level of probability of finding differences) $* *$ at $5 \%$ (very high) $*$ at $10 \%$ (high).

Source: (Forero et al, 2012).

\section{Table 10}

Relationship between net agricultural income and the rural poverty line. Colombia ten agricultural areas, 2012

\begin{tabular}{|c|c|c|c|c|c|}
\hline \multirow{2}{*}{$\begin{array}{c}\text { Net } \\
\text { agricultural }\end{array}$} & \multicolumn{5}{|c|}{ Ten zones } \\
\cline { 2 - 4 } income / & $\mathrm{L}$ & $\mathrm{M}$ & $\mathrm{S}$ & Differences & Total \\
\cline { 2 - 4 } poverty line & 44.11 & 6.59 & 1.58 & \multirow{\star}{*}{ LM LS } & 6.03 \\
\cline { 2 - 4 } \cline { 6 - 6 } & $2 \%$ & $14 \%$ & $4 \%$ & MS & $5 \%$ \\
\hline
\end{tabular}

Note: To understand the indicator LM, LS and MS, consider the explanations indicated in Table 7.

Source: (Forero et al, 2012). 
This study concluded that agricultural producers, regardless of the scale of their productive activity, manage to be efficient when they access favorable environmental conditions, and that small producers, as well as family farmers, clearly show not only efficiency but also the ability to generate economic development and effective solutions to rural poverty ${ }^{4}$

\subsubsection{Importance of small producers in national agricultural production.}

According to Leibovich et al., in Perfetti (2013), small producers, considered as those who carry out their activity in farms less than the equivalent of two-Family Agricultural Units (UAF) represent $72 \%$ of the 2.9 million workers linked to agriculture and contribute between $50 \%$ and $68 \%$ of national production (pp 189; 193).

\subsubsection{Micro-scale economies.}

The micro-scale economies arise from the direct relationship of the small producer with his crop lots and his animals, which leads him to implement specific management practices that result in an efficient use of his labor, as well as of the contracted workers. and the farm's resources (Forero, 2010).

According to Berry (2017) in 2014, small units generated almost all permanent work, those with less than five hectares generated $66 \%$ and those with less than 50 hectares $93.7 \%$ while occupying only the $24.7 \%$ of the territory, the difference corresponding to a work / land ratio 45 times higher in units of less than 50 hectares in relation to those of more than 50.

\footnotetext{
${ }^{4}$ It should be clarified that the results of large, medium and small producers are valid for the universe of the population considered, while those of family farming are valid only at the level of the selected sample.
} 


\section{Discussion and conclusions}

Evidently, the results for Colombia derived from the treaty with the United States have been negative, because so far, the country still does not have sufficient comparative advantages to compete with that market, since only 3 of the 60 groups of products analyzed have advantages sustainable comparatives over time, a very minimal amount that is reflected in the limited exportable supply and in turn in the deficit trade balance with the United States.

Otherwise, coverage in subsidies for agricultural insurance, credit, access to machinery and technical assistance is limited at a national level, different from the destination granted with the US Farm Bill (2014-2018; 2018-2023), situations that become complex with the notorious decrease in the budget for investment in the vulnerable rural population in the present National Development Plan.

The high percentage of monetary and multidimensional rural poverty and the little progress in terms of land restitution is considerable, figures that are aggravated by the high concentration of rural property and the expansion of crops destined for agribusiness and agrofuels, all this shows that Colombia has an obvious risk as far as its food sovereignty is concerned.

On the other hand, the participation of the peasant economy in agriculture continues to be of the order of $70 \%$, contributing with its economies of scale to the country's food security and confirming its efficiency even in the difficult environments of violence where they operate. 
Despite the fact that both the previous and current governments have undertaken actions to mitigate these indices, the figures are still considerably high, so it is recommended to take radical measures to recover land, especially the vacant lots accumulated irregularly by part of national and foreign multinationals (CONTRALORÍA GENERAL DE LA REPÚBLICA, 2014).

Therefore, it is recommended to increase investment for infrastructure and public goods, including access to improved water sources, expansion of coverage in technical assistance, innovation and technological development of the rural area, promotion of rural educational systems that respond to realities of life in the countryside and that allow the study of alternative production techniques, the effective advance of the policy of restitution of lands despoiled by the conflict, expansion of national coverage in subsidies for credit, insurance, agricultural machinery, implement effective measures that mitigate low educational attainment in the countryside and educational backwardness, through education aimed at promoting development in the countryside for rural families and thus reduce informal work rates in rural areas.

The foregoing is formulated within the framework of the United Nations Declaration on the Right to Development (1986), where the States must adopt, at the national level, all the necessary measures for the realization of the right to development and guarantee, among others things, equal opportunities for all in terms of access to basic resources, education, health services, food, housing, employment and a fair distribution of income. 


\section{Appendix A. Main export products to the United States}

\section{Table 11}

Colombia's bilateral trade with the United States. Main export products to the United States

\begin{tabular}{|c|c|c|c|c|c|c|c|}
\hline \multirow{3}{*}{ Descriptive } & \multicolumn{7}{|c|}{ Thousands of USD FOB } \\
\hline & \multirow[t]{2}{*}{2017} & \multirow[t]{2}{*}{2018} & \multirow[t]{2}{*}{2019} & \multicolumn{2}{|c|}{ Enero-abril } & \multirow{2}{*}{$\begin{array}{c}\text { Var \% } \\
2020 / 2019 \\
\end{array}$} & \multirow{2}{*}{$\begin{array}{l}\text { Part. \% } \\
2020 \\
\end{array}$} \\
\hline & & & & 2019 & 2020 & & \\
\hline Crude petroleum or bituminous mineral oils. & $4.463 .552,5$ & $4.334 .555,7$ & $4.898 .842,9$ & $1.901 .075,2$ & $1.082 .200,6$ & $-43,1$ & 36,4 \\
\hline $\begin{array}{l}\text { Flowers and buds, cut for bouquets or ornaments, } \\
\text { fresh, dried, bleached, dyed, impregnated or otherwise } \\
\text { prepared. }\end{array}$ & $1.091 .606,7$ & $1.138 .912,8$ & $1.149 .308,3$ & $399.830,8$ & $420.686,4$ & 5,2 & 14,2 \\
\hline $\begin{array}{l}\text { Coffee, whether or not roasted or decaffeinated; coffee } \\
\text { husk and husk; coffee substitutes containing coffee in } \\
\text { any proportion. }\end{array}$ & $1.149 .364,6$ & $1.058 .067,6$ & $1.052 .993,4$ & $393.321,9$ & $338.544,3$ & $-13,9$ & 11,4 \\
\hline $\begin{array}{l}\text { Petroleum or bituminous oils, except crude oils; } \\
\text { preparations not elsewhere specified or included, with } \\
\text { a petroleum or bituminous mineral oil content greater } \\
\text { than or equal to } 70 \% \text { by weight, in which these oils } \\
\text { constitute the base element; oil waste. }\end{array}$ & $728.279,0$ & $1.360 .137,7$ & $1.522 .202,0$ & $523.449,1$ & $254.482,8$ & $-51,4$ & 8,6 \\
\hline $\begin{array}{l}\text { Gold (including platinum gold), unworked, semi-worked } \\
\text { or in powder. }\end{array}$ & $941.872,0$ & $537.028,5$ & $513.161,0$ & $172.281,3$ & $220.399,2$ & 27,9 & 7,4 \\
\hline $\begin{array}{l}\text { Constructions and their parts (for example: bridges and } \\
\text { their parts, towers, masts, piers, columns, roof trusses, } \\
\text { roofs, doors and windows and their frames, counter } \\
\text { frames and thresholds, railings) of aluminum, except } \\
\text { prefabricated constructions of the heading } 94.06 \text {; } \\
\text { aluminum sheets, bars, profiles, tubes and the like } \\
\text { prepared for construction. }\end{array}$ & $115.454,8$ & $147.562,6$ & $227.218,3$ & $70.691,9$ & $58.540,9$ & $-17,2$ & 2,0 \\
\hline Bananas, including plantains, fresh or dried. & $160.835,8$ & $169.641,6$ & $148.862,7$ & $46.658,3$ & $52.764,2$ & 13,1 & 1,8 \\
\hline $\begin{array}{l}\text { Coals; briquettes, ovoids and solid fuels or similar } \\
\text { obtained from coal. }\end{array}$ & $338.260,4$ & $144.725,8$ & $200.611,9$ & $66.956,8$ & $35.766,4$ & $-46,6$ & 1,2 \\
\hline $\begin{array}{l}\text { Extracts, essences or concentrates of coffee, tea or } \\
\text { yerba mate and preparations based on these products } \\
\text { or based on coffee, tea or yerba mate; roasted chicory } \\
\text { and other roasted coffee substitutes and their extracts, } \\
\text { essences and concentrates. }\end{array}$ & $61.034,3$ & $62.066,9$ & $70.980,8$ & $20.362,6$ & $28.324,9$ & 39,1 & 1,0 \\
\hline
\end{tabular}




\begin{tabular}{|c|c|c|c|c|c|c|c|}
\hline $\begin{array}{l}\text { Cane or beet sugar and chemically pure sucrose, in } \\
\text { solid state. }\end{array}$ & $53.812,7$ & $71.051,9$ & $67.224,9$ & $17.137,7$ & $26.429,3$ & 54,2 & 0,9 \\
\hline $\begin{array}{l}\text { Fruits or other fruits and other edible parts of plants, } \\
\text { otherwise prepared or preserved, whether or not with } \\
\text { the addition of sugar or other sweetener or alcohol, not } \\
\text { elsewhere specified or included. }\end{array}$ & $38.592,4$ & $46.726,7$ & $50.408,9$ & $14.267,8$ & $15.615,7$ & 9,4 & 0,5 \\
\hline $\begin{array}{l}\text { Articles for transport or packaging, of plastic; stoppers, } \\
\text { lids, caps and other closure devices of plastic. }\end{array}$ & $24.945,5$ & $37.495,1$ & $44.859,5$ & $13.523,4$ & $14.997,0$ & 10,9 & 0,5 \\
\hline $\begin{array}{l}\text { Pipe fittings (for example, fittings [fittings], elbows, } \\
\text { sleeves) made of cast iron, iron or steel. }\end{array}$ & $17.807,6$ & $38.555,6$ & $51.353,8$ & $10.286,9$ & $13.780,8$ & 34,0 & 0,5 \\
\hline $\begin{array}{l}\text { Fish fillets and other fish meat (even minced), fresh, } \\
\text { chilled or frozen. }\end{array}$ & $40.987,0$ & $52.852,6$ & $44.377,4$ & $12.263,5$ & $13.647,7$ & 11,3 & 0,5 \\
\hline $\begin{array}{l}\text { Electric accumulators, including their separators, even } \\
\text { if they are square or rectangular. }\end{array}$ & $24.968,4$ & $24.817,1$ & $25.505,1$ & $10.435,7$ & $9.591,2$ & $-8,1$ & 0,3 \\
\hline $\begin{array}{l}\text { Subtotal } \\
\text { Participation \% } \\
\text { Total exported to the United States }\end{array}$ & $\begin{array}{r}9.251 .373,6 \\
87,2 \% \\
10.615 .214,4\end{array}$ & $\begin{array}{r}9.234 .198 .1 \\
86,5 \% \\
10.674 .259,9\end{array}$ & $\begin{array}{r}10.067 .910,6 \\
87,4 \% \\
11.520 .118,7\end{array}$ & $\begin{array}{r}3.672 .542,8 \\
88,9 \% \\
4.129 .609,5 \\
\end{array}$ & $\begin{array}{r}2.585 .771,4 \\
87,1 \% \\
2.969 .594,3 \\
\end{array}$ & $\begin{array}{l}-29,6 \\
-28,1\end{array}$ & $\begin{array}{r}87,1 \\
100,0\end{array}$ \\
\hline
\end{tabular}

Source: Ministry of Commerce, Industry and Tourism -Mincit (2020). 


\section{APPENDIX B. Revealed Comparative Advantage Method}

The method of the Center for Prospective Studies and International Information (CEPII) called Revealed Comparative Advantages (RCA) carried out by (De-Saint-Vaulry, 2008) was used. The CEPII indicator measures comparative advantages in a standard way, revealing them through an analysis of exchanges, as the index initially proposed by Balassa (1965) and has its antecedents in David Ricardo's theory of "comparative advantage".

Below is the calculation formulated:

$R C A_{k i t}:=\frac{1000}{Y_{i t}}\left[X^{\prime}{ }_{k i t}-M^{\prime}{ }_{k i t}-v_{k t} \sum_{k=1}^{K}\left(X^{\prime}{ }_{k i t}-M^{\prime}{ }_{k i t}\right)\right] \in \mathrm{R}$

where:

$Y_{i t}$ is the GDP of country $i$ in time $t$

$v_{k t}:=W_{k t} / W_{t}$

$W_{k t}:=\sum_{i=1}^{n}\left(X_{k i t}+M_{k i t}\right) ; W_{t}:=\sum_{k=1}^{k} W_{k t}$

$X^{\prime}{ }_{k i t}:=X_{k i t} \cdot e_{k t} ; M^{\prime}{ }_{k i t}:=M_{k i t} \cdot e_{k t}$

$e_{k t}:=1$ si $W_{k t} / W_{t}=0$; otherwise $e_{k t}:=\frac{W_{k r} / W_{r}}{W_{k t} / W_{t}}$

The evaluated zone may be the world, the members of the World Trade Organization (WTO), or a group of at least two countries, however the index and the variables that enable its calculation refers only to the selected zone. The identification of a country that belongs to a zone is identified by the letter $i$, a group of products by the letter $k$ and a time 
period by the letter $t$. "The variable denotes the $R C A_{k i t}$ index of country $i$ with respect to the product (or group of products) $k$ in period $t$ (and within the zone)". (Stellian \& Danna p. 133)

The starting point is $W_{k t}$, which represents trade in $k$ by all the countries in the zone in period $t, X_{\text {kit }}$ denotes total exports by country $i$ in time $t$, for the $K$ product groups considered in the nomenclature, otherwise $X_{k i t} \in \mathbb{R}_{+}$represents exports of $k$ (in monetary units) made by country $i$ in time-period $t$.

Once $W_{k t}$ has been calculated for each $k$, it is possible to sum $W_{1 t}+W_{2 t}+\ldots W_{k t}$ and calculate $W_{t}$, which represents "global" trade defined as the trade in all $K$ product groups in $t$ by all countries in the zone. The coeffcient $e_{k t}$ is determined by selecting a "reference period" denoted by the letter $r$. Thus, $W_{k t} / W_{r}$ is the share of $k$ in global trade in the reference period $r$. It is assumed that $W_{k t} / W_{r}$ reflects the structural factors of $k$ trade irrespective of short-term fluctuations.

Continuing with Stellian \& Buitrago, $i$ denotes Colombia, to identify Colombia's comparative (dis)advantages in the bilateral trade zone with the United States (then $n=2$ ). Data for exports and imports are taken from UNCTADstat (unctadstat.unctad.org), supplied according to the three-digit SITC Rev.3 nomenclature.

The evaluation period was from the implementation of the treaty and the joint bias was 2014. 


\section{Declarations}

Availability of data and material: All data generated or analyzed during this study are included in this published article (and its supplementary information files).

Conflicts of interest/Competing interests: Author A received a financial incentive as a young graduate researcher for having been selected in the Intern Call 016-2019, carried out by the General Directorate of Research of the Santiago de Cali University.

Author B who provided advice and consultancy for this research as a Professor, did not receive financial support.

Funding: This work was supported by the General Direction of Research from the University Santiago de Cali under Grant [number 016-2019]. Project Title: Application of Competition Law Factors in Latin American Contexts of the 21st Century. Code: 559-

621119-645. Research Line: Great Problems of Contemporary Law. Research Group: GICPODERI.

Authors' contributions: Author A (Melissa Vargas) was in charge of compiling the sources and consulting the literature for the research in accordance with the methodology outlined, prepared the Monthly Activity Reports before the General Directorate of Investigations, wrote the final article and prepared the videos for the Socialization and Communication Strategy

Author B (Rodrigo Núñez) was in charge of providing all the advice during the preparation of the research, received the Monthly Activity Reports, evaluated the projected methodological strategy, and approved the final article. 


\section{Acknowledgments}

We thank the Faculty of Law of the Santiago de Cali University, directed by its Dean, Dr. Jenniffer Marin, the Director of the Master's Degree in Law, Dr. Viviana Ramírez, and the General Direction of Research directed by Dr. Rosa del Pilar Cogua for giving us the opportunity to investigate a topic so relevant to the vulnerable rural population of our country.

\section{References}

Abreu, J. L. (2015). Analyis to the Research Method. Daena (International Journal of Good Conscience), 10(1), 205-214. Retrived July 2, 2020 from, http://web.a.ebscohost.com.banrep.basesdedatosezproxy.com/ehost/pdfviewer/pdfvi ewer?vid=3\&sid=0f31abd2-a83e-466e-8351-8fac05447bed\%40sdc-v-sessmgr02

Balassa, B. (1965). Trade liberalization and 'revealed' comparative advantage. The Manchester School, 33(2).

Berry, A. (2017). Advancement and failure in Colombian agriculture, 20th and 21st centuries. Bogotá: Editorial Universidad del Rosario.

Boddewyn, J. (1965). The Comparative Approach to the Study of Business Administration. The Academy of Management Journal, 8(4), 261-267. Retrived October 12, 2020 from http://www.jstor.org.banrep.basesdedatosezproxy.com/stable/255342

Colombia - United States Trade Promotion Agreement. Annex 2.3 Tariff Elimination. Retrived April 12, 2020 from http://www.sice.oas.org/trade/col_usa_tpa_e/Text_e.asp\#Annex23 
Colombia - United States Trade Promotion Agreement. Chapter Two: National Treatment and Market Access for Goods. Retrived May 23, 2020 from http://www.sice.oas.org/tpd/and_usa/COL_USA/Draft_text_0607_e/asset_upload_fi le145_10148.pdf

Colombia - United States Trade Promotion Agreement. Colombia Appendix I. Retrived May 20, 2020 from http://www.sice.oas.org/trade/col_usa_tpa_e/asset_upload_file348_10183.pdf

Colombia - United States Trade Promotion Agreement. General Notes. Tariff Schedule of the Republic of Colombia. Retrived May 15, 2020 from http://www.sice.oas.org/trade/col_usa_tpa_e/asset_upload_file898_10184.pdf

Colombia - United States Trade Promotion Agreement. United States Appendix I. Retrived April 23, 2020 from http://www.sice.oas.org/trade/col_usa_tpa_e/asset_upload_file422_10168.pdf

Colombian Commission of Jurists. (2019). Radiography of Land Restitution in Colombia. Bogotá Retrieved March 30, 2020, from https://www.coljuristas.org/documentos/tmp/Radiografia_de_la_restitucion_de_tierr as_en_Colombia_2019.pdf

Congressional Research Service. (September 26, 2019). What is the farm bill? Retrived August 13, 2020 from https://fas.org/sgp/crs/misc/RS22131.pdf

Constitutional Court. (July 24, 2008). Sentence C-751 of 2008. Retrived from http://www.secretariasenado.gov.co/senado/basedoc/c-751_2008.html 
CONTRALORÍA GENERAL DE LA REPÚBLICA. (2014). Irregular Accumulation of Vacant Lands in the Colombian Altillanura. Bogotá. Retrived March 11, 2020 from https://www.contraloria.gov.co/documents/20181/703164/Inf_Baldios_pub2017.pdf /fc83b206-c806-414e-a253-6bf355b01ccf

Balassa, B. (1965). Trade liberalization and 'revealed' comparative advantage. The Manchester School, 33(2).

Buendía Rice, E. A. (2013). El papel de la Ventaja Comparativa en el desarrollo económico de los países. Revista Análisis Económico, XXVIII(69), 55-78. Retrived september $1^{\text {st }}, 2020$ from https://www.redalyc.org/articulo.oa?id=413/41331033004

De Saint-Vaulry, A. (2008). "Base de données CHELEM - commerce international du CEPII". Document de travail CEPII(9).

El Tiempo. (February 20, 2018). "We have not yet reached the promised land: balance of land restitution in Colombia". Retrived April 5, 2020 from https://www.eltiempo.com/datos/balance-de-la-restitucion-de-tierras-en-colomba119708

Figueroa Torres, L. (2017). Analysis of the feasibility of appying indexed insurante for the agricultural sector in Colombia. Master's Degree Thesis in Finance. Bucaramanga: Santander University UDES. Retrived August 20, 2020 from https://repositorio.udes.edu.co/bitstream/001/609/1/An\%C3\%A1lisis\%20de\%201a\% 20viabilidad\%20de\%20aplicaci\%C3\%B3n\%20de\%20los\%20seguros\%20indexados \%20para\%20e1\%20sector\%20agr\%C3\%ADcola\%20en\%20Colombia.pdf 
Forero Álvarez, J. (2010). The Colombian peasant, between the economic protagonism and the ignorance of society. Bogotá: Faculty of Environmental and Rural Studies. Pontifical Javeriana University.

Forero, J., Garay, L. J., Barbieri, F., Ramírez, C., Suárez, D. M., \& Gómez, R. (2012). The economic efficiency of large, medium and small Colombian agricultural producers. En L. J. Garay Salamanca, R. Bailey, J. Forero A., F. Barbieri Gómez , C. Ramírez G., D. M. Suárez V., . . S. Perry, Reflections on rurality and territory in Colombia (p.p. 69-113). Bogotá: Corcas Editors SAS.

Fund for the Financing of the Agricultural Sector-FINAGRO. (2019). Finagro Management Report. Retrived August 24, 2020 from https://www.finagro.com.co/sites/default/files/idgs2019_.pdf

Fund for the Financing of the Agricultural Sector-FINAGRO. (2020). Finagro. 2020 Service Portafolio. Bogotá. Retrived April 11, 2020 from https://www.finagro.com.co/sites/default/files/portafolio_finagro_2020_2.pdf

Law 1753 of 2015 "By which the National Development Plan is issued 2014-2018: All for a new country". (2015). Retrived June 12, 2020 from https://www.sic.gov.co/sites/default/files/documentos/LEY-175315\%20Plan\%20Nacional\%20de\%20Desarrollo\%202014\%20-\%202018.pdf

Law 1955 of May 25, 2019 "By which the 2018-2022 National Development Plan is issued. "Pact for Colombia, Pact for Equity". (2019). Retrived June 12, 2020 from https://colaboracion.dnp.gov.co/CDT/Agriculturapecuarioforestal\%20y\%20pesca/El 
\%20CAMPO\%20COLOMBIANO\%20UN\%20CAMINIO\%20HACIA\%20EL $\% 20$

BIENESTAR\%20Y\%20LA\%20PAZ\%20MTC.pdf

Leibovich, J., Botello, S., Estrada, L., \& Vásquez, H. (2013). Linking small producers to the devolpment of agriculture. En J. J. Perfetti, Á. Balcázar, A. Hernández, \& J. Leibovich, Policies for the development of agriculture in Colombia (p.p. 187-233). Bogotá: Fedesarrollo, Sociedad de Agricultores de Colombia (SAC), Incoder, Finagro, Banco Agrario. Retrived April 30, 2020 from https://www.repository.fedesarrollo.org.co/bitstream/handle/11445/61/LIB_2013_P ol\%C3\%ADticas\%20para\%20el\%20desarrollo\%20de\%20la\%20agricultura_Compl eto.pdf?sequence $=1 \&$ isAllowed $=\mathrm{y}$

Ministry of Agriculture and Rural Development, Rural Agricultural Planning Unit (UPRA). (2016). Analysis of the Distribution of Rural Property in Colombia. Methodological Proposal. Bogotá D.C, Colombia. Retrived February 9, 2020 from http://bibliotecadigital.agronet.gov.co/handle/11438/8635

Ministry of Commerce, Industry and Tourism. (2020). Macroeconomic Context of the United States. Retrived July 20, 2020 from https://www.mincit.gov.co/CMSPages/GetFile.aspx?guid=504145cb-c956-4a8399d0-abbe53b1c457

Ministry of Commerce, Industry and Tourism-Mincit.Trade Promotion Agreement between the Republic of Colombia and the United States of America. Retrived March 4, 2020 from http://www.tlc.gov.co/acuerdos/vigente/acuerdo-de-promocioncomercial-entre-la-republ-1 
National Administrative Department of Statistics-DANE. (2016 e). Third National Agricultural Census-Volume 2. Bogotá. Retrived March 12, 2020 from https://www.dane.gov.co/files/images/foros/foro-de-entrega-de-resultados-y-cierre3-censo-nacional-agropecuario/CNATomo2-Resultados.pdf

National Administrative Department of Statistics-DANE. (2020a). Trade Balance according to economic groups and main countries. 1995-2020p. Bogotá. Retrived August 4, 2020 from https://www.dane.gov.co/index.php/estadisticas-portema/comercio-internacional/balanzacomercial\#: :text=EEn\%20el\%20periodo\%20enero\%2Dseptiembre,US\%247.818\% 2C4\%20millones\%20FOB.\&text=La\%20balanza\%20comercial\%20es\%20la,e\%20i mportaciones\%20de\%20un\%20pa\%C3\%A

National Administrative Department of Statistics-DANE. (2020b). Technical Bulletin Monetary Poverty in Colombia. Year 2019. Bogotá. Retrived August 12, 2020 from https://www.dane.gov.co/files/investigaciones/condiciones_vida/pobreza/2019/Bole tin-pobreza-monetaria_2019.pdf

National Administrative Department of Statistics-DANE. (July 14, 2020c). Multidimensional Poverty Results. Press conference presentation. Retrived August 13,2020 from https://www.dane.gov.co/files/investigaciones/condiciones_vida/pobreza/2019/Pres entacion_rueda_de_prensa_ECV_e_IPM_2019.pdf

National Administrative Department of Statistics-DANE. (2020d). National Agricultural Survey -ENA 2019. Bogotá. Retrived August 11, 2020 from 
https://www.dane.gov.co/files/investigaciones/agropecuario/enda/ena/2019/boletin_ ena_2019.pdf

National Planning Department. Pluriannual Investment Plan 2018-2022. Retrived June 13, 2020 from 2020, de https://colaboracion.dnp.gov.co/CDT/Prensa/PNDPPI20182022n.pdf

Organization of American States (OAS). Foreign Trade Information System. Colombia United States Trade Promotion Agreement. Summary. Retrived February 10, 2020 from http://www.sice.oas.org/TPD/AND_USA/Studies/COLResumen_s.pdf

Oxfam. (2017). Radiography Report of Inequality. OxfamInternational. Retrived March 13, 2020 from https://d1tn3vj7xz9fdh.cloudfront.net/s3fspublic/file_attachments/radiografia_de_la_desigualdad.pdf

Stellian, R., \& Danna Buitrago, J. P. (2017). Colombian agricultural product cometitiveness under the free trade agreement with the United States: analysis of the comparative advantages. CEPAL Review(122), 127-149. Retrived April 4, 2020 from https://repositorio.cepal.org/bitstream/handle/11362/42664/RVI122_Stellian.pdf?se quence $=1 \&$ isAllowed $=\mathrm{y}$

United Nations. Human rights. Office of the High Commissioner. (1986). Declaration on the right to development. Adopted by the General Assembly in its resolution 41/128, of December 4, 1986. Retrived July 12, 2020 from https://www.ohchr.org/sp/professionalinterest/pages/righttodevelopment.aspx\#: :te $\mathrm{xt}=\mathrm{Art} \% \mathrm{C} 3 \% \mathrm{ADculo} \% 206-$ ,1.,\%2C\%20sexo\%2C\%20idioma\%20y\%20religi\%C3\%B3n. 
World Trade Organization (WTO). (2016). WTO Agreements Series. Agriculture. 3.

Retrived August 13, 2020 from

https://www.wto.org/english/res_e/booksp_e/agric_agreement_series_3_e.pdf

Zamora, A., \& Monterroso, I. (2017). The participatory prospective analysis (PPA). A regional and local vision on the security of communal tenure of land and forests in Madre de Dios. Center for International Forestry Research, 3-4. Retrived April 12, 2020 from http://www.jstor.org/stable/resrep16300.6 
Figures

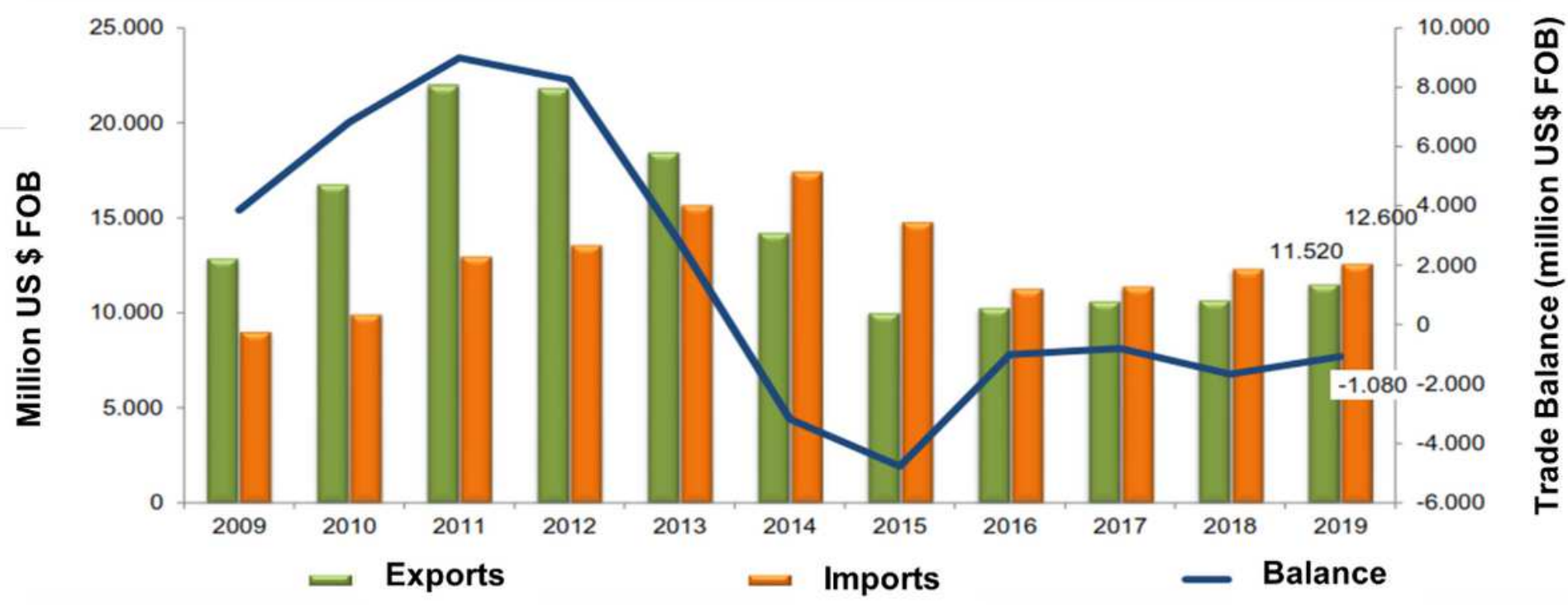

Figure 1

Trade balance (millions of USD \$ FOB) Colombia and the United States 2009-2019. Source: Ministry of Commerce, Industry and Tourism-Mincit (2020).

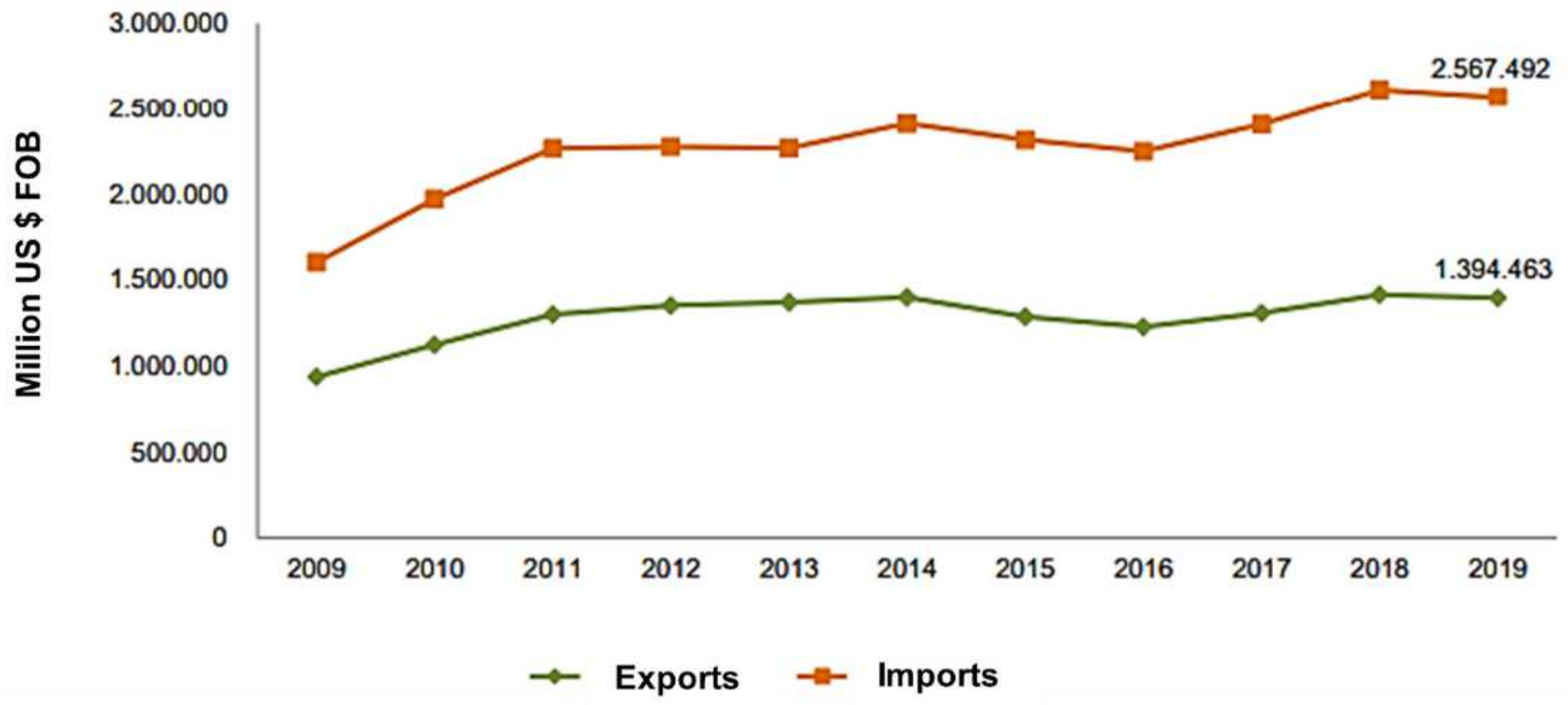

Figure 2

Foreign trade of goods (Millions of USD). Source: Ministry of Commerce, Industry and Tourism-Mincit (2020). 


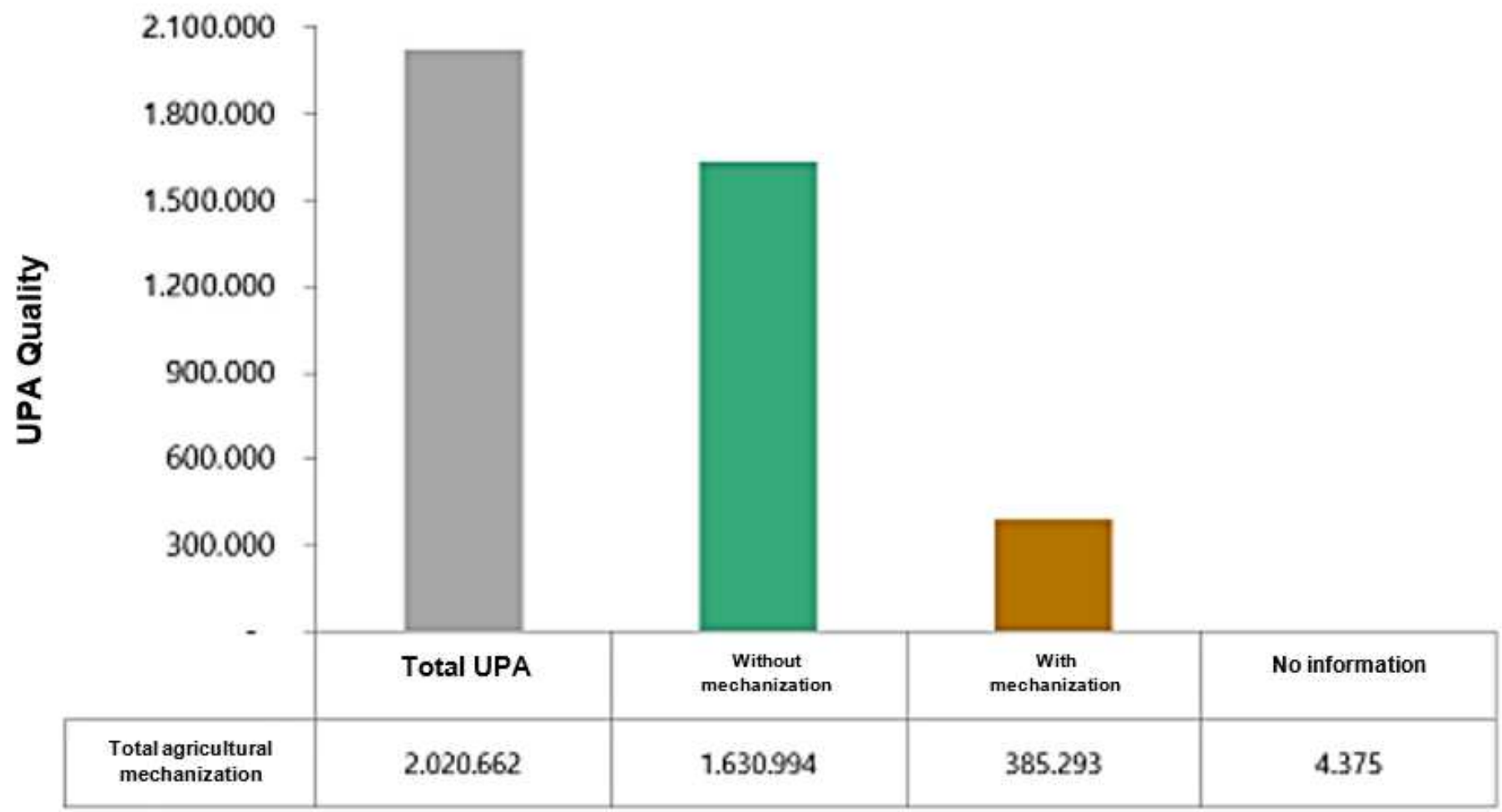

Figure 3

Amount of UPA, by use of agricultural machinery in the different agronomic phases of the crops. National total. First semester 2019. Source: DANE, National Agricultural Survey ENA (2020) 


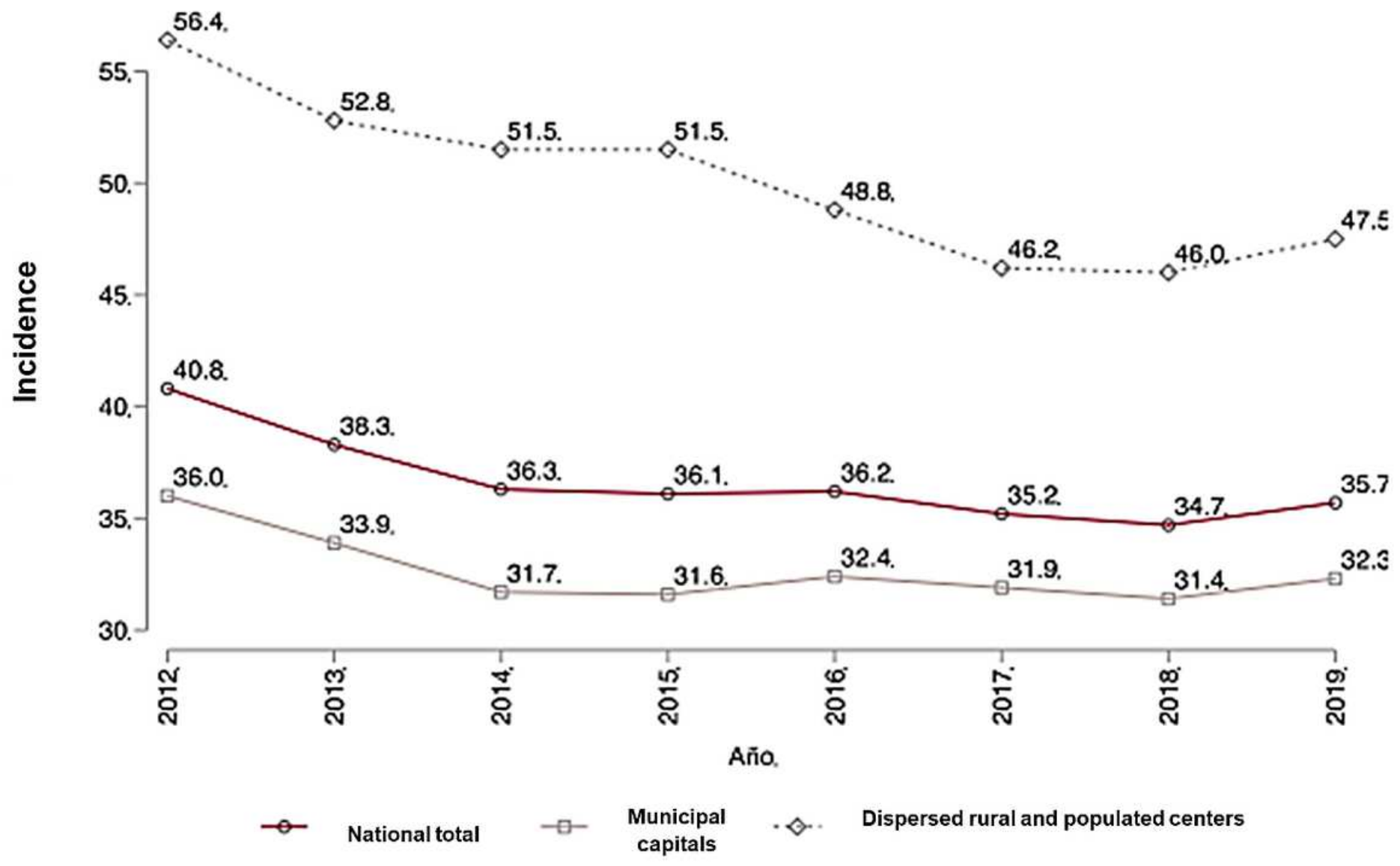

Figure 4

Incidence of Monetary Poverty (percentage). National total, headwaters and populated centers and dispersed rural. 2012-2019 Source: National Administrative Department of Statistics-DANE (2020b). 


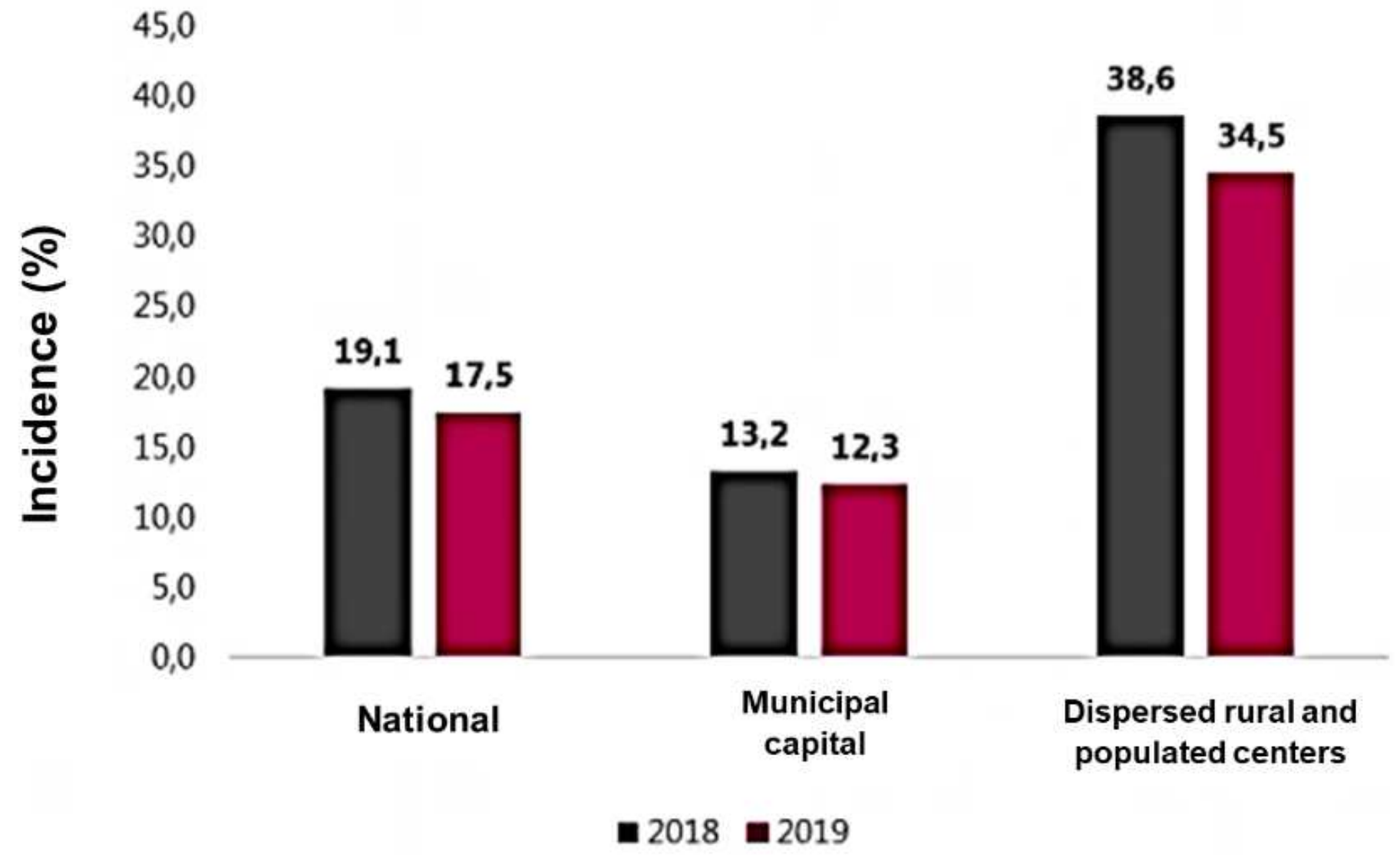

Figure 5

Incidence of multidimensional poverty- Major domains 2018 and 2019 Source: National Administrative Department of Statistics -DANE (2020c).

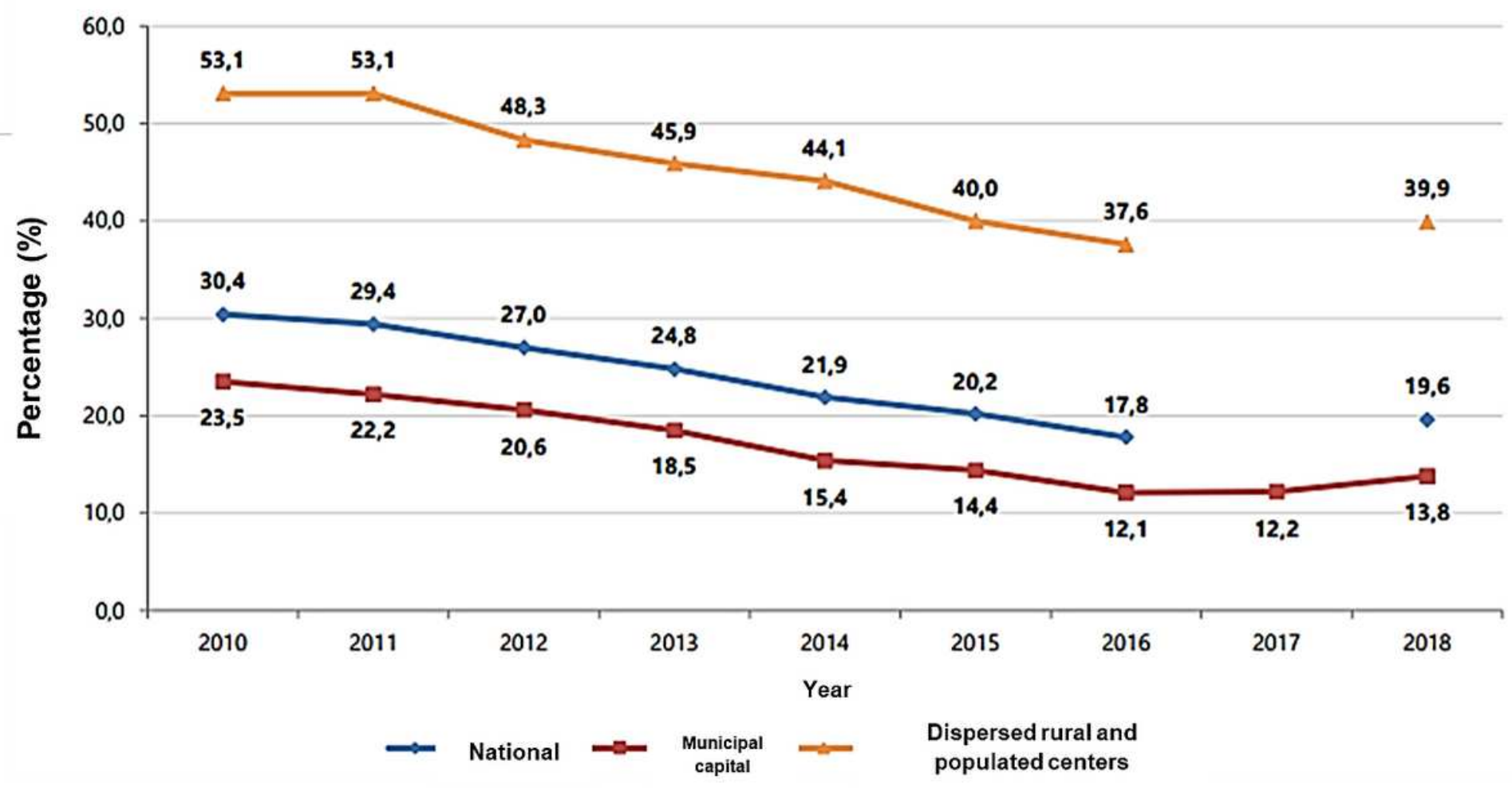


Figure 6

Multidimensional Poverty Results. Quality of Life Survey ECV 2010-2018. The estimates were made using the expansion factors of the 2005 Census. Source: Administrative Department of Statistics-DANE. (2020c). Press conference presentation.

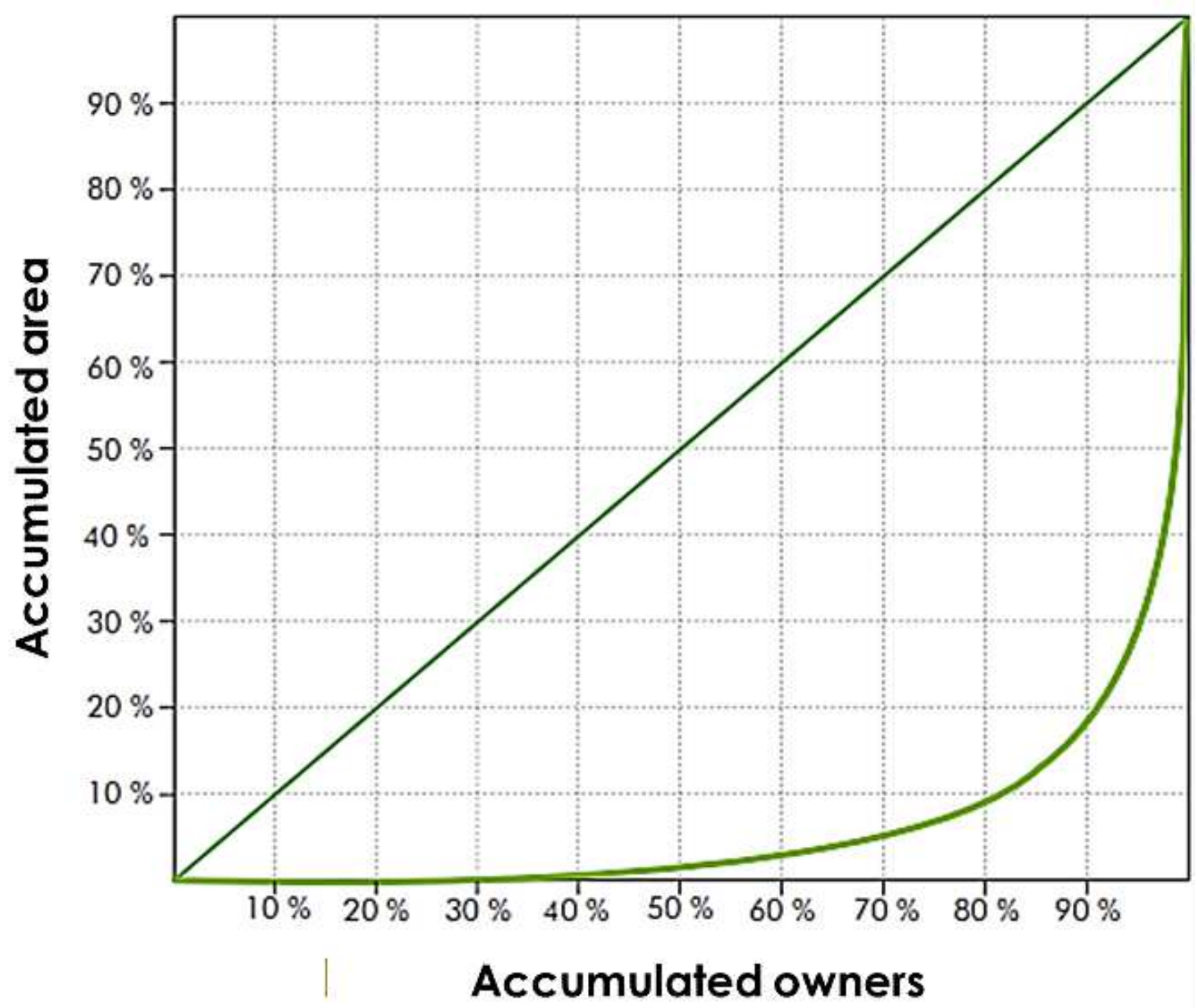

Lorenz

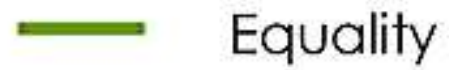

Figure 7

Colombia: Lorenz curve for the area of owners of private rural properties with agricultural destination (2014) Source: Ministry of Agriculture and Rural Development, Rural Agricultural Planning Unit -UPRA (2016). 


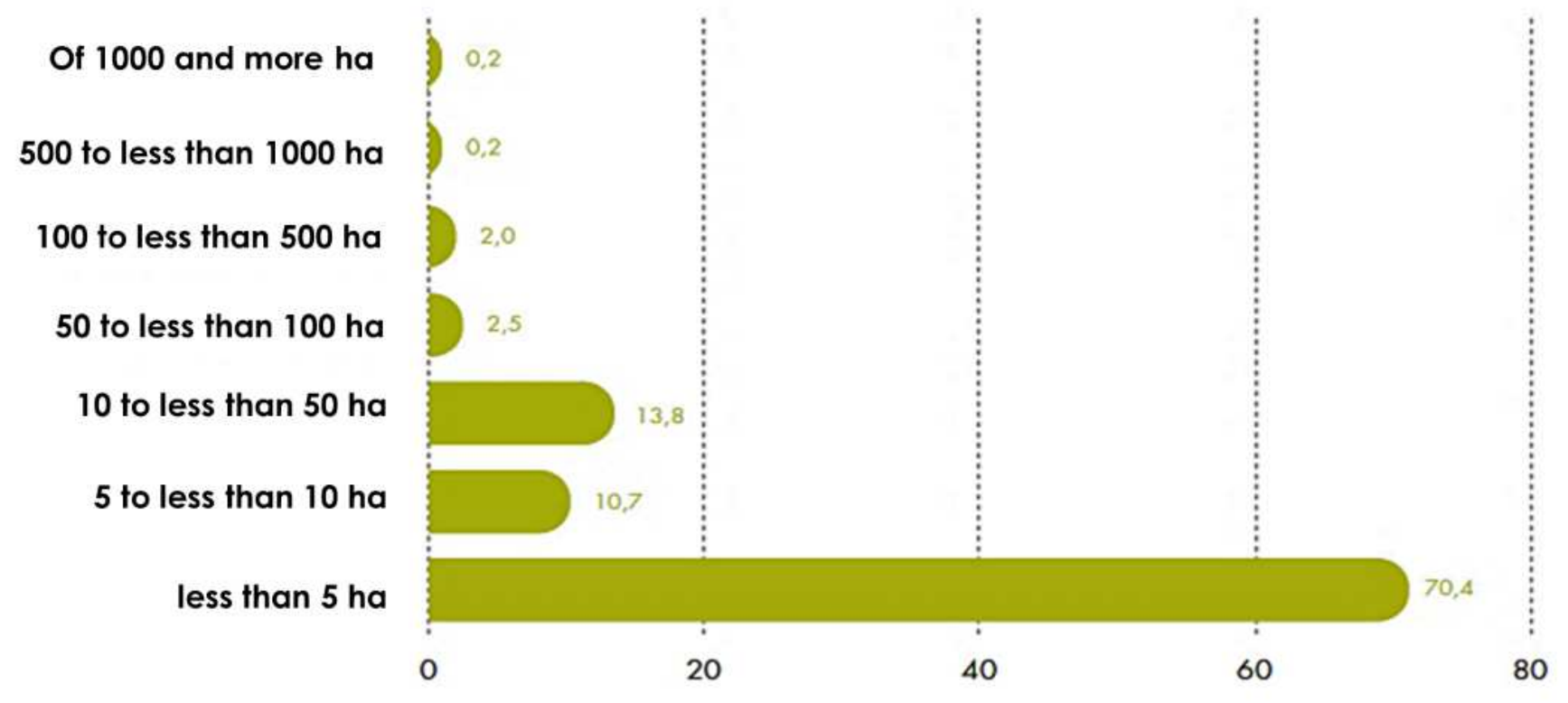

Figure 8

Distribution (\%) of the number of UPAs in the dispersed rural area surveyed, according to size (ha) Source: National Administrative Department of Statistics-DANE (2016 e).

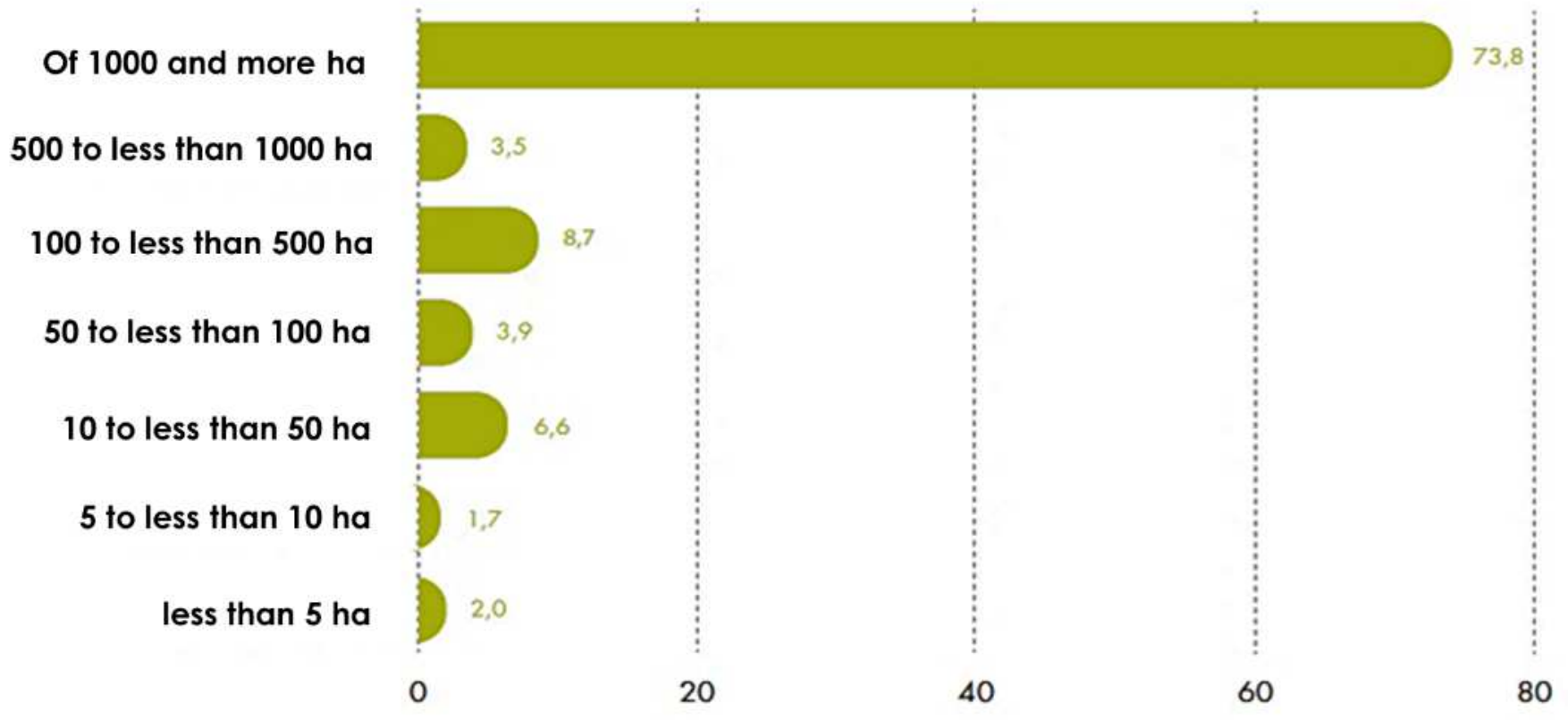

Figure 9

Distribution (\%) of the number of UPAs in the dispersed rural area surveyed, according to size (ha) Source: National Administrative Department of Statistics-DANE (2016 e). 


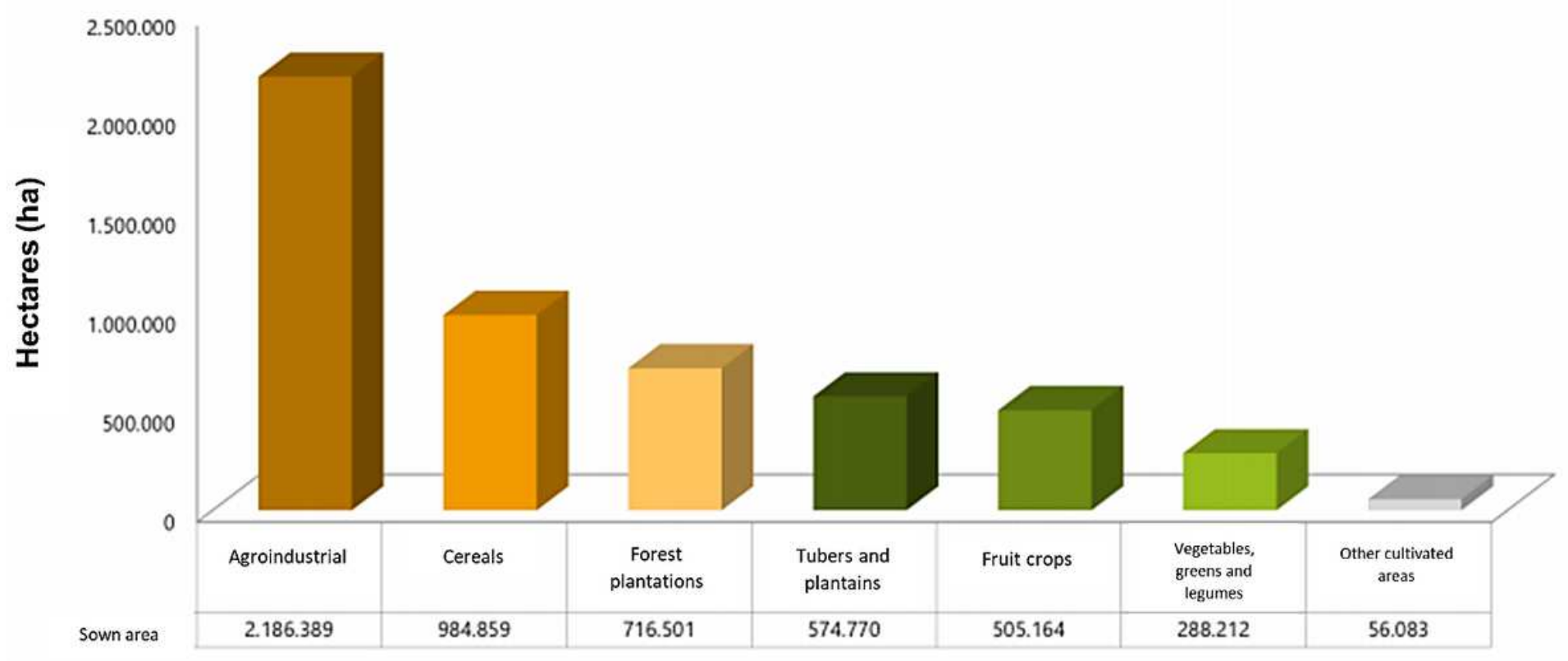

Figure 10

Sown area or planted by crop groups (hectares) National total. 2019 Source: National Administrative Department of Statistics-DANE (2020d).

\section{Supplementary Files}

This is a list of supplementary files associated with this preprint. Click to download.

- Appendix.docx 